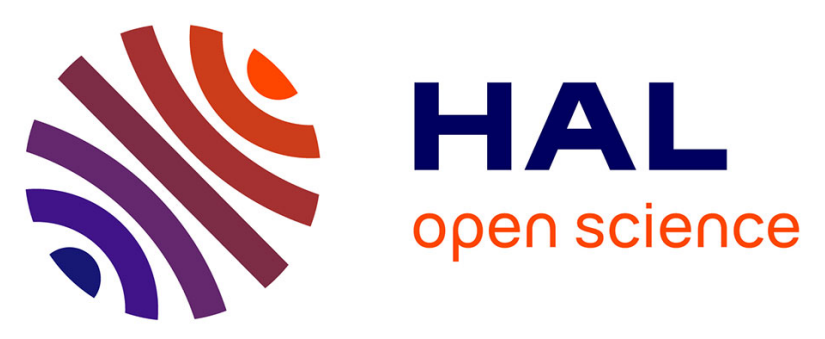

\title{
A late antique vegetation history of the Western Mediterranean in context
}

José-Antonio Lopez-Saez, Sebastián Pérez Díaz, Didier Galop, Francisca Alba-Sanchez, Daniel Abel-Schaad

\section{- To cite this version:}

José-Antonio Lopez-Saez, Sebastián Pérez Díaz, Didier Galop, Francisca Alba-Sanchez, Daniel AbelSchaad. A late antique vegetation history of the Western Mediterranean in context. Late Antique Archaeology, 2018, Environment and society in the long late Antiquity, 11, pp.93-114. hal-01869981

\section{HAL Id: hal-01869981 \\ https://hal-univ-tlse2.archives-ouvertes.fr/hal-01869981}

Submitted on 7 Sep 2018

HAL is a multi-disciplinary open access archive for the deposit and dissemination of scientific research documents, whether they are published or not. The documents may come from teaching and research institutions in France or abroad, or from public or private research centers.
L'archive ouverte pluridisciplinaire HAL, est destinée au dépôt et à la diffusion de documents scientifiques de niveau recherche, publiés ou non, émanant des établissements d'enseignement et de recherche français ou étrangers, des laboratoires publics ou privés. 


\title{
A Late Antique Vegetation History of the Western Mediterranean in Context
}

\author{
José Antonio López-Sáez, Sebastián Pérez-Díaz, Didier Galop, Francisca Alba-Sánchez \\ and Daniel Abel-Schaad
}

\begin{abstract}
Fossil pollen records from 70 sites with reliable chronologies and high-resolution data in the western Mediterranean, were synthesised to document Late Holocene vegetation and climate change. The key elements of vegetation dynamics and landscape construction during Late Antiquity are clear in the light of the fossil pollen records. These are: fire events (natural or anthropogenically induced); grazing activities in high-mountain areas; agriculture; arboriculture; and human settlement in the lowlands. In terms of anthropogenic pressure, the differences recorded between highlands and lowlands suggest an imbalance in land use. Such practices were related to three main types of activities: wood exploitation and management, cultivation, and pastoralism. In lowland areas there seems to be some synchronism in vegetation dynamics during the late antique period, since most of the territories of the western Mediterranean had been deforested by the Early Roman period. However, in mountainous regions, pollen records document a clear asynchrony.
\end{abstract}

\section{Introduction}

Knowledge of the impact of climate change on social vicissitudes, and associated human responses, can provide an historical reference point for dealing with current and future global climate change. The impact of climate change is the result of interactions among a variety of factors in both natural and social systems, and at multiple spatial and temporal scales. ${ }^{1}$ During recent decades, the western Mediterranean region has aroused great interest in the study of Late Quaternary landscapes, as this region is very sensitive to climate change. It has also witnessed strong human influence, through polyculture, intensive grazing and deliberate use of fire, for millennia. Fossil pollen data from lakes and peat bog deposits have been frequently used in vegetation and climate reconstructions, as they tend to reflect vegetation and climate changes at a regional scale. In this sense, reconstruction of past vegetation has become important in order to understand environmental and land use changes. This

1 Gil-Romera et al. (2010); Dearing et al. (2015). article will thus review the existing environmental evidence for the western Mediterranean from $300 \mathrm{BC}$ to $\mathrm{AD}$ 1000, and will compare it with relevant archaeological and historical data.

The western Mediterranean is an enormously complex territory from an orographic, biogeographical and historical point of view, and it is therefore extremely difficult to present a detailed synthesis without taking into account the uniqueness of each of the concerned territories. Therefore, in this article, we have decided to consider certain geographical areas separately, and ultimately discern possible asynchronism or synchronism between vegetation evolution and anthropic dynamics. ${ }^{2}$ Through land-use change, human activity could have brought about synchronous or asynchronous changes in vegetation composition, depending on the particularities and possibilities of exploitation of each territory.

However, available pollen records from the western Mediterranean have been primarily focused on the Pleistocene-Holocene transition, or on the potential impact of Prehistoric communities, or rapid climate changes, on the environment during the Mid Holocene. ${ }^{3}$ In contrast, high-resolution and continuous pollen series, which extend over the last two millennia, are limited. In this review, we used 70 fossil pollen records from the western Mediterranean (fig. 1). Our review and synthesis differ from earlier published reviews, ${ }^{4}$ as we applied a uniform set of site-selection criteria, and mostly used recent pollen data. The objectives of this paper will be to assess regional vegetation patterns by synthesising fossil pollen records, and to evaluate and understand vegetation response to climate change and/ or human impact.

2 De Beaulieu et al. (2005); Giesecke et al. (2011); Luterbacher et al. (2012).

3 Carrión et al. (2010); Carrión et al. (2012); Fletcher and Zielhofer (2013); Carrión et al. (2015).

4 Hernández-Beloqui (2011); Hernández-Beloqui et al. (2015). The synthetic nature of this review means that only the most useful and relevant pollen data will be shown and discussed, so some collected types will be omitted.

(C) KONINKLIJKE BRILL NV, LEIDEN, 2018 | DOI:10.1163/22134522-12340054 Adam Izdebski and Michael Mulryan (eds) Environment and Society in the Long Late Antiquity (Late Antique Archaeology 11 - 2018) (Leiden 2018), pp. 93-114 


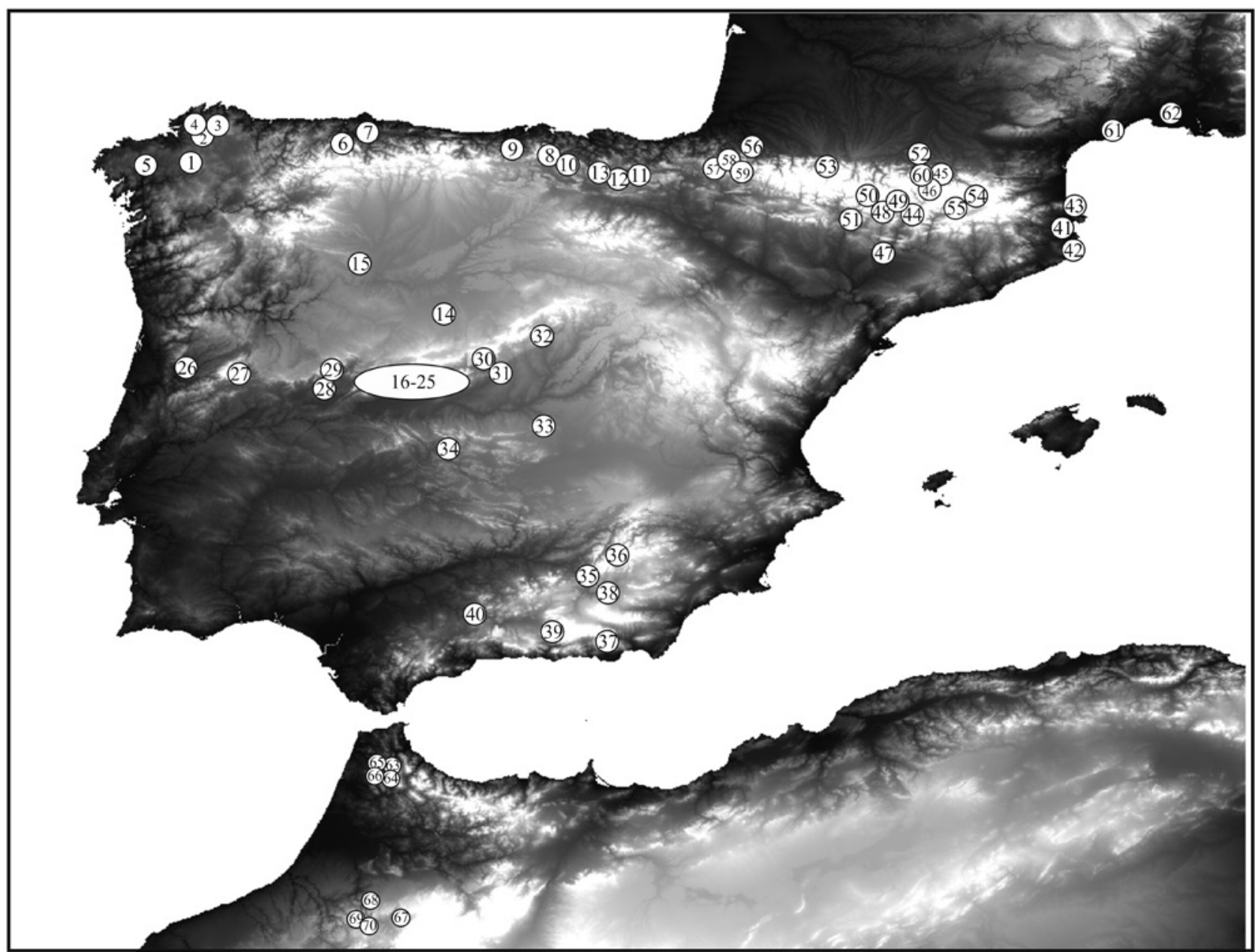

FIgUre 1 Pollen records mentioned in the text: 1, Cruz do Bocelo; 2, Pena da Cadela; 3, Borralleiras da Cal Grande; 4, Penido Vello; 5 , Braña Rubia; 6, Alto de la Espina; 7, Monte Areo; 8, Sotombo; 9, Culazón; 10, Zalama; 11, Fuente del Vaquero; 12, Randulanda; 13, Arreo; 14, Almenara de Adaja; 15, Villafáfila; 16, Lanzahíta; 17, Serranillos; 18, Pozo de la Nieve; 19, Redondo; 20, Tiemblo; 21, Ojos Albos; 22, Peña Negra; 23, Fuente de la Leche; 24, Fuente del Pino Blanco; 25, Labradillos; 26, Charco da Candieira; 27, El Payo; 28, Maíllo; 29, La Meseguera; 30, Rascafría; 31, Peñalara; 32, Somolinos; 33, Tablas de Daimiel; 34, Patateros; 35, Siles; 36, Ojos de Villaverde; 37, Gádor; 38, Cañada de la Cruz; 39, Borreguil de la Caldera; 40, Zóñar; 41, Castelló; 42, Sobrestany; 43, Portlligat; 44, Montcortès; 45, Pla de Soulcem; 46, Pla de Labinas; 47, Estanya; 48, Prats de Vila; 49; Estanilles; 50, Redon; 51, Basa de la Mora; 52, Pélissié; 53, Col d'Ech; 54, Pla de l'Orri; 55, Pradell; 56, Gabarn; 57, Quinto Real; 58, Sourzay; 59, Artxilondo; 6o, Orri de Théo; 61, Palavas; 62, La Calade; 63, Fifi; 64, Aanasser; 65, Maison Forestière; 66, Dayet M'Had; 67, Sidi Ali; 68, Tifounassine; 69, Taguelmam n'Harcha; 7o, Tigalmamine.

\section{Methodological Considerations}

The geographical area considered in this review covers the Iberian Peninsula (Spain and Portugal), southwestern and south-eastern France, and north-western Africa (Morocco). Abundant pollen records of various time spans and data quality are available for this area, however, many records tend to have low temporal resolution and can be discontinuous. In this study, we selected pollen sites based on three criteria: (i) a reliable chronology with a minimum of three dating control points over the last 2,300 years; (ii) high sampling resolution with a minimum of 5 o years per sample; and (iii) a continuous record covering most of the Late Holocene without a documented depositional hiatus. A total of 70 lake and peat sites are included as they fulfill these criteria. There are no satisfactory records for south-western Iberia and south-western France, and for the northern and southern Iberian plateaus there are only a few records. Therefore, we have included two sequences with a lower resolution when we discuss the general vegetation and climate history. Pollen data were obtained from the original authors or digitised from pollen diagrams in published material.

Radiocarbon dating was the geochronological technique used for all pollen records in this synthesis. All dates for the reviewed sequences have been calibrated or recalibrated to calendar years BC (before Christ) 
or AD (anno Domini), using the latest IntCalı3 calibration dataset. ${ }^{5}$ An age-depth model was produced for each site using Clam 2.2 software. The best fit was obtained by applying a smoothing spline to the available radiocarbon dates. The confidence intervals of the calibrations and the age-depth models were calculated at $95 \%(2 \sigma)$, with 1,00o iterations. Pollen percentages were calculated from the count data, and were based on the sum of all terrestrial pollen excluding aquatic taxa, spores and non-pollen palynomorphs.

For discursive convenience, we organised the sites into seven geographical areas, as described below. We present and discuss 13 summary pollen diagrams, that are representative of the vegetation changes in these regions of different vegetation types.

\section{Northern Iberia}

\section{Galician Mountains (sites 1-5)}

In the north-western part of the Iberian Peninsula, several pollen records of peaty deposits (Cruz do Bocelo, Pena da Cadela, Borralleiras da Cal Grande, Penido Vello and Braña Rubia $\left.{ }^{6}\right)$, on the Galician Mountains (6oo-9oo masl), show the development of mesophilous forests (Alnus, Corylus, deciduous Quercus) during the Iron Age. However, evidence of human impact is detected ca. $350-270$ BC by the increase of coprophilous fungi and nitrophilous taxa, indicative of animal husbandry.

The most dramatic environmental change occurred at the transition from the Iron Age to the Roman period ca. $200 \mathrm{BC}$, when mesophilous forest suffers a large decline in favour of grasslands, while coprophilous fungi and nitrophilous taxa strongly increase. Although the forest recovers $c a .170 \mathrm{BC}$, thereafter, deforestation was more or less continuous from Roman times until AD 1300. This was characterised by two major phases of forest clearance: the first one during the Roman period (ca.16о вС-AD 200); and the second during the Germanic era ( $c a$. AD 450-700). Both phases are synchronous with grassland expansion, an increase in agricultural and tree crops (Castanea, Olea), and livestock activity.

\section{Cantabrian Range (sites 6-9)}

Four high-resolution pollen records are available in this region. In the lowlands, the pollen sequences of Monte Areo (200 masl), Culazón (582 masl) and Alto

5 Blaauw (2010); Reimer et al. (2013).

6 Törnqvist et al. (1989); Muñoz-Sobrino et al. (2005); Mighall et al. (2006); Silva-Sánchez et al. (2014). de la Espina-La Molina $(650 \text { masl })^{7}$ peat bogs, show the permanence of dense deciduous forests (Quercus robur type, Corylus, Betula, Alnus) and heathlands (Erica) during the Late Iron Age (fig. 2-top). At higher altitudes, the Sotombo pollen record (1290 masl $)^{8}$ shows a similar situation, namely dominant mixed forests of hazel, oak and beech, heaths and grasslands, below a belt likely consisting of high-mountain pine forests (Pinus sylvestris type). Coprophilous fungi and Cerealia are attested at this time in Sotombo, suggesting transterminant-grazing activities (fig. 2-bottom).

During the Early Roman period (ca. 20 BC-AD 240), deciduous Quercus and Corylus are still the most abundant trees in the lowlands, although cultivated ones such as Castanea sativa, Olea europaea and Juglans regia show a more regular presence. In the highlands, forests remain stable, except for some development of heathlands and the expansion of beech to the detriment of hazel in Sotombo. This period documents a very significant change, characterised by high values of hydro-hygrophytes (Cyperaceae, Myriophyllum, Potamogetonaceae, Typha) in the Alto de la Espina record (fig. 2-top), suggesting an important rise in the water-table level from $c a$. AD 20, likely related to its Roman use as a water-deposit associated with mining activities. This is followed by several phases of a drawdown $c a$. AD 150 and 200 (probably drainage). Additionally, agricultural practices close to the wetland, as the high values of cereals suggest, could be related to the mining period during the early Roman empire.

During the Late Roman period ( $c a$. AD 240-450) the forests remain relatively stable in the lowlands, with less cereal and olive cultivation, and an increasing pastoral pressure (high values of coprophilous fungi). In the highlands, beech becomes more important, like grasslands, while heathlands are significantly reduced. This situation remains stable during the Germanic period ( $c a$. AD 450-700) in the lowlands, when permanent grazing (recurrence of coprophilous fungi) is the most prominent feature, while Cerealia is almost absent. In contrast, in the highlands the situation is quite different, with declining high-mountain pine and oak forests, while hazel and grassland spread, and cereals and walnuts grow again in the Sotombo pollen record.

Tree cover (Quercus robur type, Corylus, Betula) gradually diminishes through the Middle Ages ( $c a$. AD 700-1300), whereas Cerealia, Castanea and Juglans

\footnotetext{
7 López-Merino et al. (2010); López-Merino et al. (2011); López-Sáez et al. (2013); González-Pellejero et al. (2014); López-Merino et al. (2014). 8 Pérez-Díaz et al. (2016a).
} 

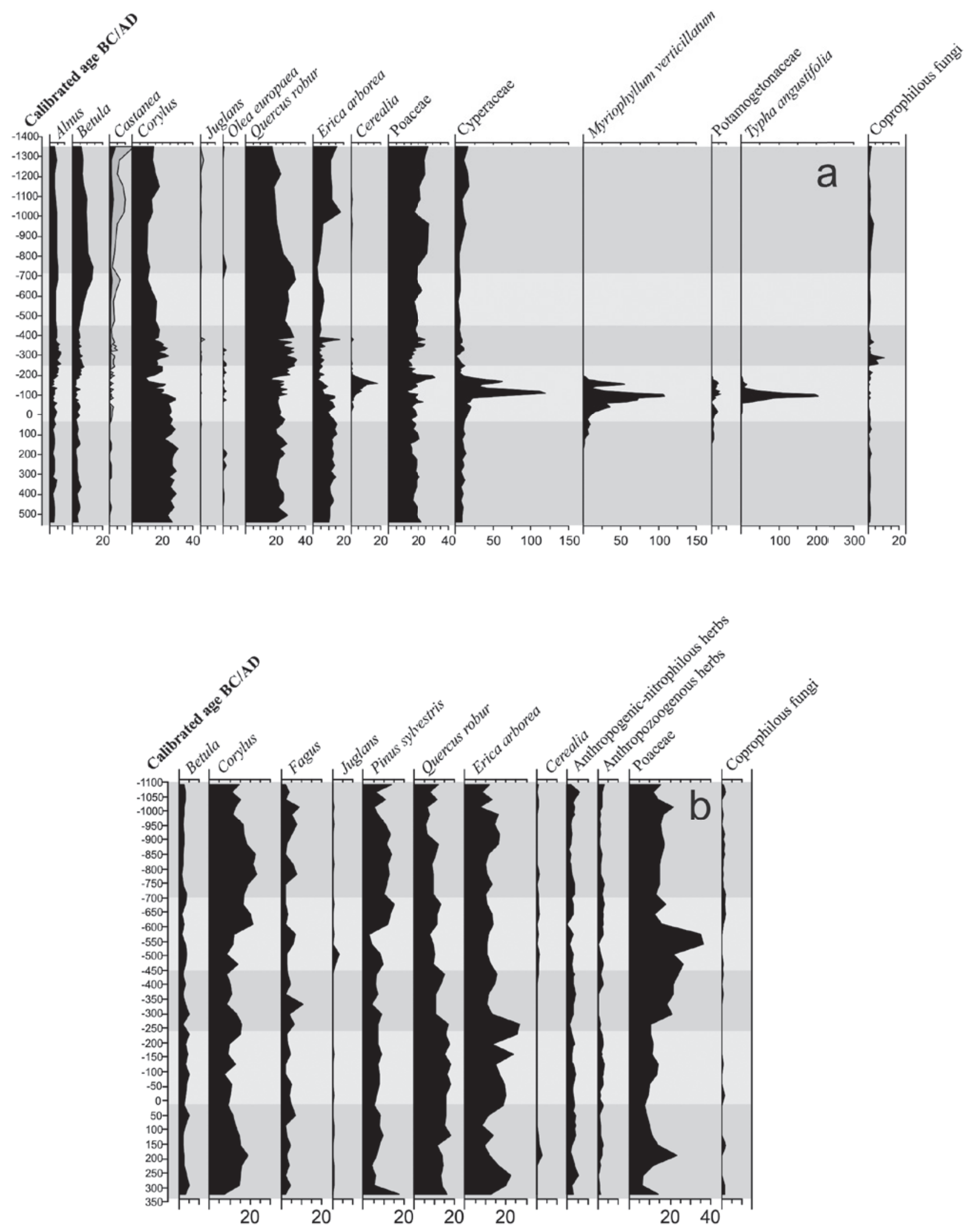

FIGURE 2 Percentage pollen diagrams of Alto de la Espina (top) and Sotombo (bottom) peat bogs for selected pollen and non-pollen palynomorph taxa. The grey bands represent the different phases described in the text. 
percentages increase again, and heathlands and grasslands extend into the lowlands. Fagus sylvatica becomes the most important tree species in the mountainous areas of the Cantabrian Range $c a$. AD $75^{\circ}$.

\section{Basque Mountains (sites 10-13)}

In the lowlands of the Basque Country at the end of the Roman period, the data show a landscape characterised by important fluctuations of tree cover $c a$. AD $0-450$. It is essentially dominated by deciduous and evergreen oaks, beech and hazel, although evidence for anthropogenic activities is documented in the pollen records of Arreo lake (655 masl) and Randulanda peat bog (807 masl; fig. 3-top) ${ }^{9}$ suggesting a non-intensive exploitation of valleys and forested areas in a humid and warm context, related to the Ibero-Roman humid period (ca. $250 \mathrm{BC}-\mathrm{AD} 450$ ). The high percentages of charcoal in the Arreo sequence indicate a high frequency of fires, most likely caused by salt exploitation of the Añana diapir in Roman times. At higher altitude, the Zalama pollen record (1330 masl $)^{10}$ also documents the great abundance of forests, particularly those of deciduous Quercus and Corylus, as well as the development of heathlands and presence of Cerealia pollen (fig. 3-bottom).

The lowlands of this region were intensively exploited ca. AD 450-790, especially by agricultural and livestock activities, shown by the development of grasslands and heathlands. We also see an increase in coprophilous fungi, suggesting intensive land use during the onset of the Early Middle Ages. The end of Roman domination in this territory caused important changes, linked with the disarticulation of hierarchies. By the mid 5 th c. AD, many Late Roman settlements were abandoned, while other, previously secondary, ones seem to become new centres. At the same time, previously untouched, marginal areas are now populated by new villages, understood as hierarchical centres with new power structures. All these large-scale transformations affected the way of life of villagers, which, judging from the pollen records of Randulanda (fig. 3-top) and Fuente del Vaquero (722 masl), translate to a somewhat more intensive exploitation of forest spaces. ${ }^{11}$ In the Zalama sequence, this period is also characterised by an increase in pastoral pressure and the development of ferns (Pteridium aquilinum). In contrast, the decrease in pastures and

9 Pérez-Díaz and López-Sáez (2012); Corella et al. (2013); PérezDíaz and López-Sáez (2014).

10 Pérez-Díaz et al. (2016b).

11 Pérez-Díaz and López-Sáez (2014); Pérez-Díaz and López-Sáez (2015). coprophilous fungi seen in the Arreo record during the Early Middle Ages, was probably linked to a decrease in salt production and the progressive depopulation of the area during an arid phase, related to the Early Medieval Cold Episode (AD 500-900).

During the High Middle Ages ( $c a$. AD 790-1200), the forests undergo a very important regression that affects both evergreen and deciduous oaks, as well as beech and hazel, in both lowlands and highlands. All taxa related to anthropogenic activities reach their maximum value at this time, such as: Cerealia, the Erica arborea type, anthropozoogenous and nitrophilous herbs, and coprophilous fungi. This period tallies with the onset of the Medieval Climate Anomaly (AD 900-1350), the most intense arid phase recorded in the pollen records, which, in the Arreo lake, is reflected by increased salinity and lower lake levels. In fact, the decreasing trend in deciduous Quercus and Fagus from the 8th c. AD in the Arreo, Fuente del Vaquero and Randulanda sequences, could be interpreted as both a progressive increase in arid conditions and a sign of increased human impact. From the 8th c. AD a dense network of medieval villages was created, in a context characterised by population growth and the expansion of cultivated areas.

\section{Central Iberia}

\section{Northern Plateau (sites 14-15)}

Pollen records from the Almenara de Adaja (784 masl) and Villafáfila (68o masl) lagoons show in great detail the vegetation dynamics during the Late Holocene, in relation to both climatic variability and anthropic activity. ${ }^{12}$ During the Early Iron Age (ca. 1000-500 BC) the climate was humid, as shown by the development of hydro-hygrophytic elements (Cyperaceae, Phragmites, Callitriche) and non-pollen palynomorphs, ${ }^{13}$ indicative of eu-mesotrophic waters, under high human impact. This is evidenced by progressive degradation of evergreen oak woodlands, high values of both anthropozoogenous and nitrophilous herbs as well as coprophilous fungi, and cereal cultivation (fig. 4). Later, an arid phase begins, extending until $c a .300 \mathrm{BC}$, with progressing xerophytic (Artemisia) and xerohalophytic (Chenopodiaceae) communities.

The period from the Late Iron Age to the end of the Roman period ( $c a .300 \mathrm{BC}-\mathrm{AD} 450$ ) shows a slight recovery of regional Scots pine forests (Pinus sylvestris

\footnotetext{
12 López-Merino et al. (2009a); López-Sáez et al. (2017a).

13 Hereafter referred as NPPs.
} 

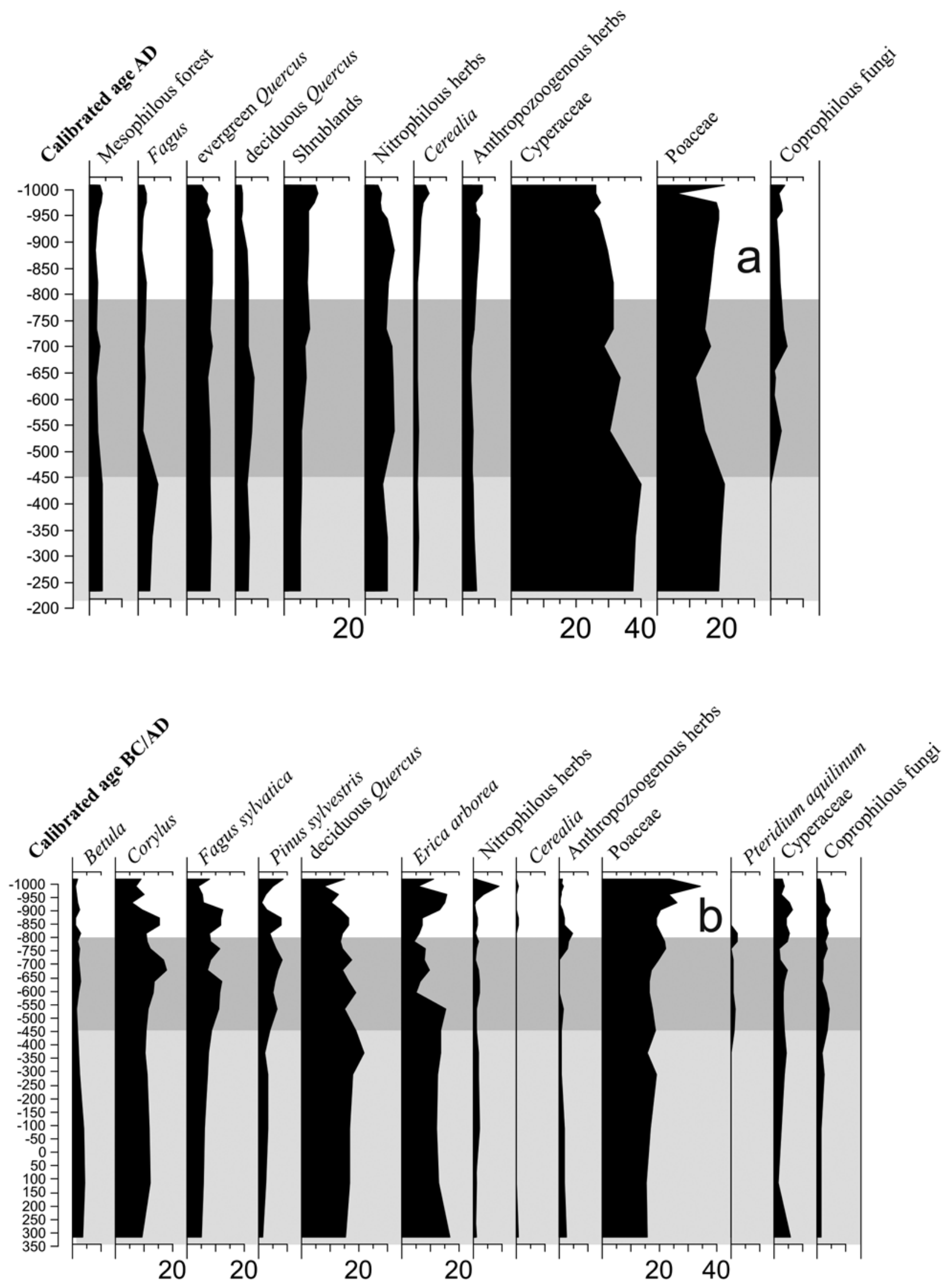

FIGURE 3 Percentage pollen diagrams of Randulanda (top) and Zalama (bottom) peat bogs for selected pollen and non-pollen palynomorph taxa. The grey bands represent the different phases described in the text. 


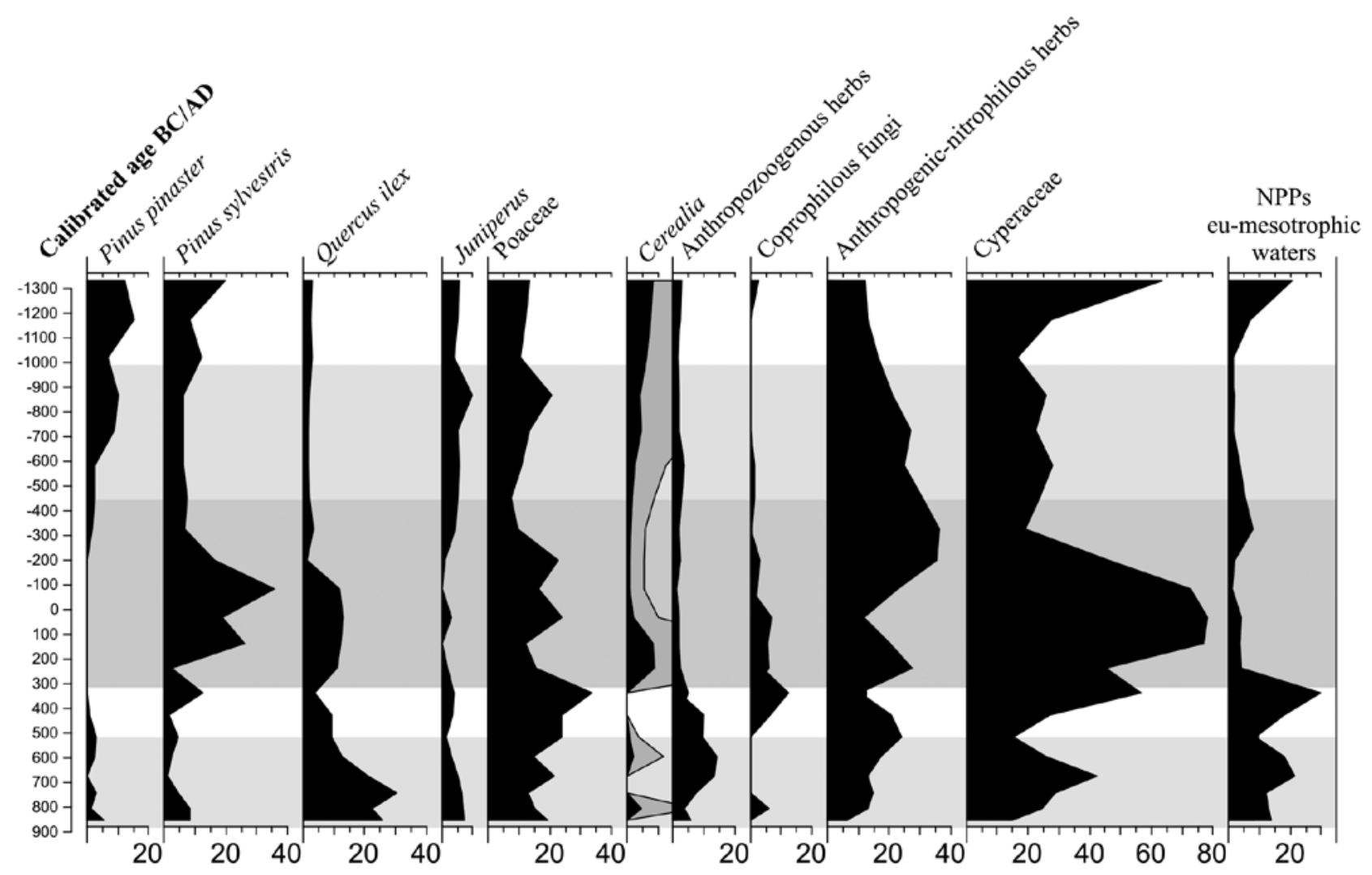

FIGURE 4 Percentage pollen diagram of Almenara de Adaja lagoon (selected pollen and non-pollen palynomorph taxa). The grey bands represent the different phases described in the text.

type) and a decrease of Pinus pinaster, although with a significant advance of anthropozoogenic nitrophilous herbs, and the presence of Cerealia pollen and coprophilous fungi at the end of the Iron Age. These findings suggest a humid climate and a temperature increase, that is the so-called Ibero-Roman humid period (ca. $25^{\circ} \mathrm{BC}-\mathrm{AD} 45^{\circ}$ ). This wet and warm period is confirmed in the Almenara de Adaja and Villafáfila pollen records by increasing values of Cyperaceae. However, the Roman period shows the progressive decline of Quercus ilex type percentages, suggesting woodland clearings accompanied by the spread of Poaceae.

Climatic conditions changed markedly with the onset of the Early Medieval Cold Episode ( $c a$. AD 450/500900/950), a period marked by lower temperatures and greater aridity. This climatic change clearly influenced the vegetation of the northern Iberian plateau in the Early Middle Ages, as evidenced by the percentage increase of Pinus pinaster and Juniperus, and the decrease of Cyperaceae and NPPs, indicative of eu-mesotrophic waters (fig. 4). An important change in vegetation composition occurred $c a$. AD 400, that is a rapid decline of Quercus ilex type and a marked rise in Poaceae. This likely indicates the definitive replacement of evergreen woodlands by grasslands and agricultural crops, so conforming to the current landscape of the greater part of the northern Iberian plateau.

\section{Iberian Central System (sites 16-32)}

The region of the western Mediterranean in which the most high-resolution pollen records are available is the Iberian Central System, particularly the Gredos Range in its central-western part, with ten palaeoenvironmental sequences (sites $16-25) \cdot{ }^{14}$ Four more are available for the Francia (sites 28-29), Gata (site 27) and Estrela (site ${ }_{26} 6$ ) ranges in the western part, ${ }^{15}$ and three others can be found for the Guadarrama ( sites 30-31) and Pela (site 32) ranges in the eastern end of the Iberian Central System. ${ }^{16}$

By the time the Romans got to central Iberia, different Celtic ethnic groups inhabited the Iberian Central System $\mathrm{ca}$. 400-50 BC. The western part was included in the Vettonia area, whereas the eastern highlands constituted the Carpetania region. In the Gredos and Gata ranges, within the Vettonian region, pollen records from

14 Blanco-González et al. (2009); López-Merino et al. (2009b); López-Sáez et al. (2009b); López-Sáez et al. (2010); Abel-Schaad and López-Sáez (2013); López-Sáez et al. (2014); López-Sáez et al. (2016a); López-Sáez et al. (2016b); López-Sáez et al. (2017b); Robles-López et al. (2017a); Robles-López et al. (2017b).

15 Van der Knaap and van Leeuwen (1995); Abel-Schaad et al. (2009); Morales-Molino et al. (2013); Abel-Schaad et al. (2014); Silva-Sánchez et al. (2016).

16 Ruiz-Zapata et al. (2007); Gómez-González et al. (2009); Currás et al. (2012). 
low (Lanzahíta, Peña Negra and El Payo: 590-1,00o masl) and mid-high-altitude (Serranillos, Redondo, Fuente de la Leche and Pozo de la Nieve: 1,380-1,80o masl) peat bogs show the presence of a well-developed pine (Pinus sylvestris type) or pine-birch forest in the highlands. In the lowlands, the record indicates Pinus pinaster (central Gredos Range), deciduous oaks-hazel (western Gredos Range), or alder-birch (Gata Range) forests (figs. 5 a and 5 b). Despite the dominance of forests, there is some evidence for anthropogenic activities linked to grazing and agriculture. Towards the westernmost part of the massif (Estrela Range), the Charco da Candieira record $(1,400$ masl) shows an area of deciduous oak woodlands and heath formations in a highly anthropised environment, with a presence of cereal pollen.

Within the Carpetanian region (Guadarrama Range), the high-altitude pollen record from Peñalara $(1,940$ masl) also shows a well-developed Scots pine forest in the highlands, and evergreen and deciduous oaks in the lowlands, with low percentages of anthropogenic pollen indicators. However, in the Lozoya-Paular valley (Guadarrama Range), the Rascafría sequence (1,113 masl) is indicative of a deforested landscape, with low tree cover and the proliferation of ruderal and anthropozoogenous taxa and shrublands. The easternmost pollen sequence, from Somolinos lake (Pela Range: 1,280 masl), shows the presence of a well-developed Scots pine forest, accompanied by evergreen and deciduous oaks, with a low representation of herbs and an increase in anthropogenic pollen indicators $c a .400$ BC. The identification of Cerealia and Secale is evidence for economically productive activities in this area, and coprophilous fungi ascospores also indicate the presence of crops and some local grazing activities.

Pollen diagrams during the Roman period show a higher intensity of human impact in low-altitude deposits around the western-central areas of the massif, such as Maíllo peat bog on the northern slopes (1,100 masl), or Lanzahíta, El Payo and Peña Negra on the southern (fig. 5-top). Arboreal pollen reaches its minimum values eastwards in Rascafría and Somolinos, pointing to pine wood deforestation, probably due to the use of timber for construction or as fuel. The high levels of Cerealia and Secale in Somolinos are also noteworthy. This is related to the existence of large urban centres and many small villages and farming communities, that are especially abundant in the eastern massif, but much rarer to the west.

In the Gredos and Estrela ranges, the landscape appears scarcely altered by human activity during the period $c a .50 \mathrm{BC}-\mathrm{AD} 45^{\circ}$, apparent in high-altitude deposits, such as those from Serranillos, Charco da Candieira, Redondo or Pozo de la Nieve (fig. $5^{\text {-bottom). }}$ However, at Fuente de la Leche, the progressive decline
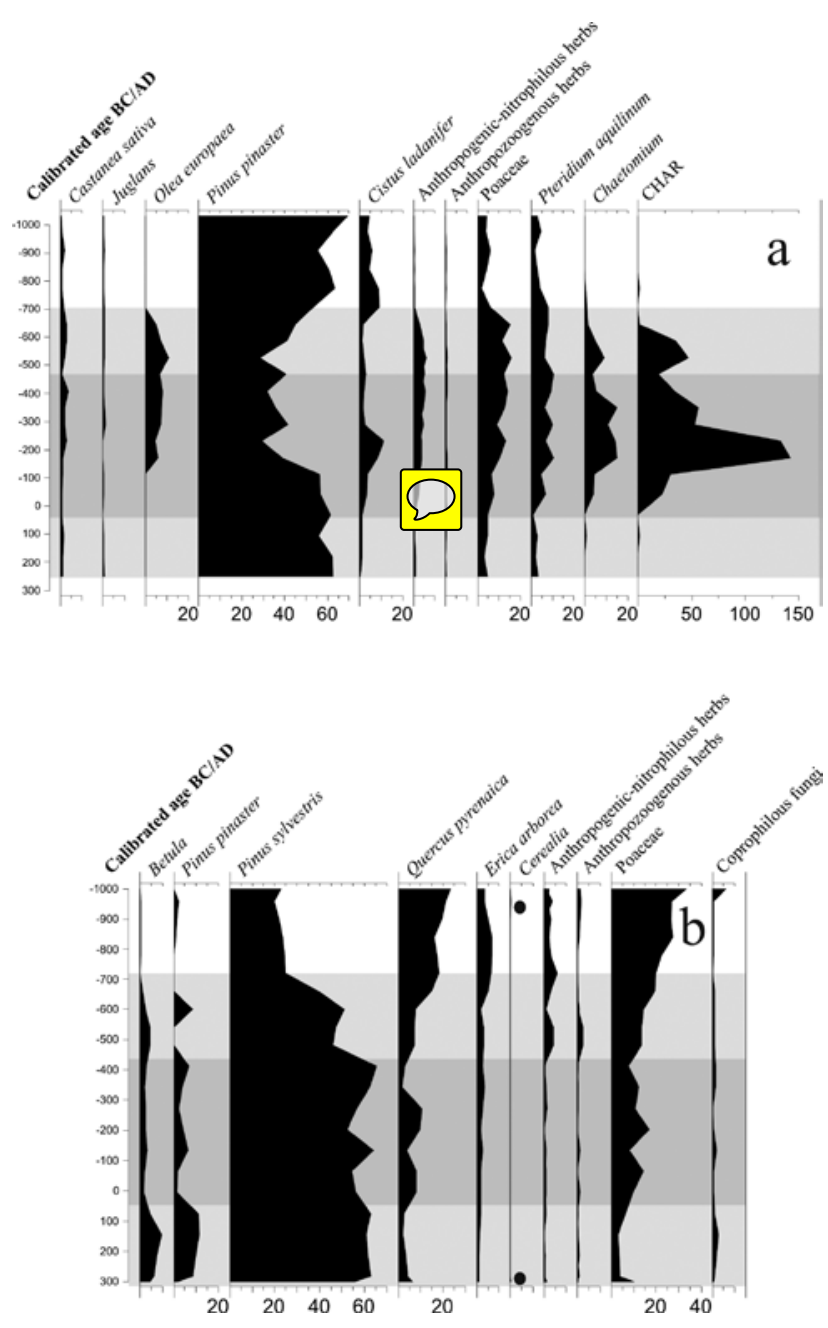

FIGURE 5 Percentage pollen diagrams of Lanzahita (top) and Pozo de la Nieve (bottom) peat bogs for selected pollen and non-pollen palynomorph taxa, and charcoal accumulation rate-CHAR. The grey bands represent the different phases described in the text.

of Pinus sylvestris type suggests the existence of woodland clearings, which are accompanied by an increase in coprophilous fungi and macrocharcoal maximum values. During the Roman period, the Gredos Range was only used as an access route to other regions; the area was marginal territory and sparsely populated due to its inhospitable character. Yet, the situation is completely different in the Guadarrama Range, judging by some of the high-altitude pollen records from there, such as at Peñalara, where, $c a$. $100 \mathrm{BC}-\mathrm{AD} 450$ the pine forests are largely absent, and anthropogenic pollen indicators show high values. However, all the high-altitude pollen records show the above-mentioned farming intensification during the Late Roman period, resulting in broader livestock pressure and a rise in pollen percentages of different crops. Castanea and Olea curves become continuous during this time in almost all cases, with a wider appearance of sweet chestnut westwards and olive tree eastwards. 
Beyond the spread of grasslands, to supply the increasing livestock density, the Iberian Central System acted as an area of transhumance through the communication network developed by the Romans, who provide the first evidence for long-distance livestock movement. The slight expansion of both evergreen and deciduous Quercus forests, favoured by the increasing temperatures and the repeated use of fire, is also significant, as is the increase in charcoal accumulation rates in most of the deposits during this period. The Tiemblo (1,250 masl) pollen record provides the first Iberian pollen sequence undertaken within a Castanea sativa-dominated woodland. This sequence is the irrefutable proof not only of the naturalness of sweet chestnut trees in central Iberia, but also of the existence of well-characterised forests of this species, during the last 3,000 years at least.

The Visigothic kingdom (AD 450-711) that evolved in Hispania after the period of Roman occupation, was based on subsistence farming, and the fall of international trade eased the pressure on forest resources. However, climatic conditions changed strikingly, with the onset of the Early Medieval Cold Episode (AD 450950 ), marked by lower temperatures and greater aridity. This climatic change clearly influenced the vegetation of the Iberian Central System in the Early Middle Ages, as evidenced in Somolinos, which reports an arid phase extending from the final decades of the Late Roman period until AD 700. Birch forests increase their representation in almost all the pollen records, favoured by the colder temperatures, possibly indicating a drop in the tree line in high-altitude deposits. However, lower records located at the westernmost area also display this spread in birch, like at El Payo or Maíllo. Forests also recover in the highest-altitude deposits of the Guadarrama Range, such as at Peñalara. Nevertheless, the Visigothic period was a phase of large deforestation processes, within a clear livestock-oriented pattern, although cropping continues. Forests were cleared to obtain new pastures, and new lands were brought into cultivation, in a period of rural habitat proliferation and land exploitation led by peasantry.

These forest clearances were mainly carried out by means of fire. This is reported in low-altitude deposits like Maíllo, Lanzahíta (fig. 5-top), Peña Negra and Rascafría, following the trend set by the Romans, but is apparent more strongly in higher altitude records, like Serranillos, Redondo, Fuente del Pino Blanco, Labradillos, Ojos Albos, Fuente de la Leche (fig. $5^{\text {-bot- }}$ tom), Pozo de la Nieve and Somolinos. This is likely related to grazing activities (high values of anthropozoogenous taxa and coprophilous fungi), in order to preserve upland pastures, but also to bring new lands into cultivation, as part of new, expansive and dynamic farming strategies. Nonetheless, some extension of olive and sweet chestnut groves is detected, especially on southern slopes. The presence of cereal pollen declines. However, rye, a cereal better adapted to low temperatures, appears on several sites during this period, like Ojos Albos or Peña Negra, pointing to increasing human pressure on the environment.

Until the effective political possession and colonisation of the Iberian Central System by the northern Christian kingdoms $c a$. AD 1080, this massif acted as a borderline between Muslim and Christian powers for several centuries ( $c a$. AD 711-1100). This was also a time of climatic transition, between the Early Medieval Cold Episode and the Late Medieval Warm Episode ( $c a$. AD 950-1350), the latter characterised by similar temperatures to the current regime, moderate rainfall, but a marked dry period from the 9th to 11th c. AD At high-altitudes sites in western areas of the massif, an initial phase of forest recovery (birch, alder and deciduous oaks) is recorded $c a$. AD 700-950 in Charco da Candieira and Redondo, as a result of a decline in livestock and farming activities. At this time, heathlands and grasslands decreased, as well as anthropozoogenous taxa, and there is no evidence for olive or sweet chestnut cultivation. The same situation is documented on the southern slopes of the Gata Range in the El Payo sequence. Conversely, at low-altitude sites in the western Gredos Range (Peña Negra), grasslands spread again by means of fire, in order to sustain the increasing livestock population. Differences between both slopes are evidenced in the Francia Range, where the Maíllo northern record shows the dominance of birch forests, while heathlands are widely spread on the southern slopes, as recorded in the La Meseguera deposit (90o masl).

A similar picture is documented in the central Gredos Range, at high-altitude sites such as Ojos Albos, Fuente de la Leche, Pozo de la Nieve and Serranillos, $c a$. AD 6801010, where high-mountain pine forests recover thanks to a cooler and drier climate. There is little evidence of anthropozoogenous taxa, coprophilous fungi, or olive cultivation, and there are low values of charcoal. In contrast, in the low-altitude pollen records of the southern slopes of the Gredos Range, such as at Lanzahíta, Pinus pinaster increase considerably, as well as Cistus ladanifer, while anthropogenic taxa (Olea, pyrophilous fungi and macrocharcoal) levels decrease $c a$. AD 710-1120. High-altitude pollen records from the Guadarrama Range, such as Peñalara, show a very clear human impact, through both the increase in anthropozoogenous taxa and decreasing tree cover. In the Lozoya-Paular valley, the Rascafría record shows a significant increase of Plantago lanceolata type $c a$. AD $800-1000$, as well as a decline in tree cover $c a$. AD 895-1170. The historical data for this period (AD 711-1100) fully corroborate the presented palynological data. They describe an economic 


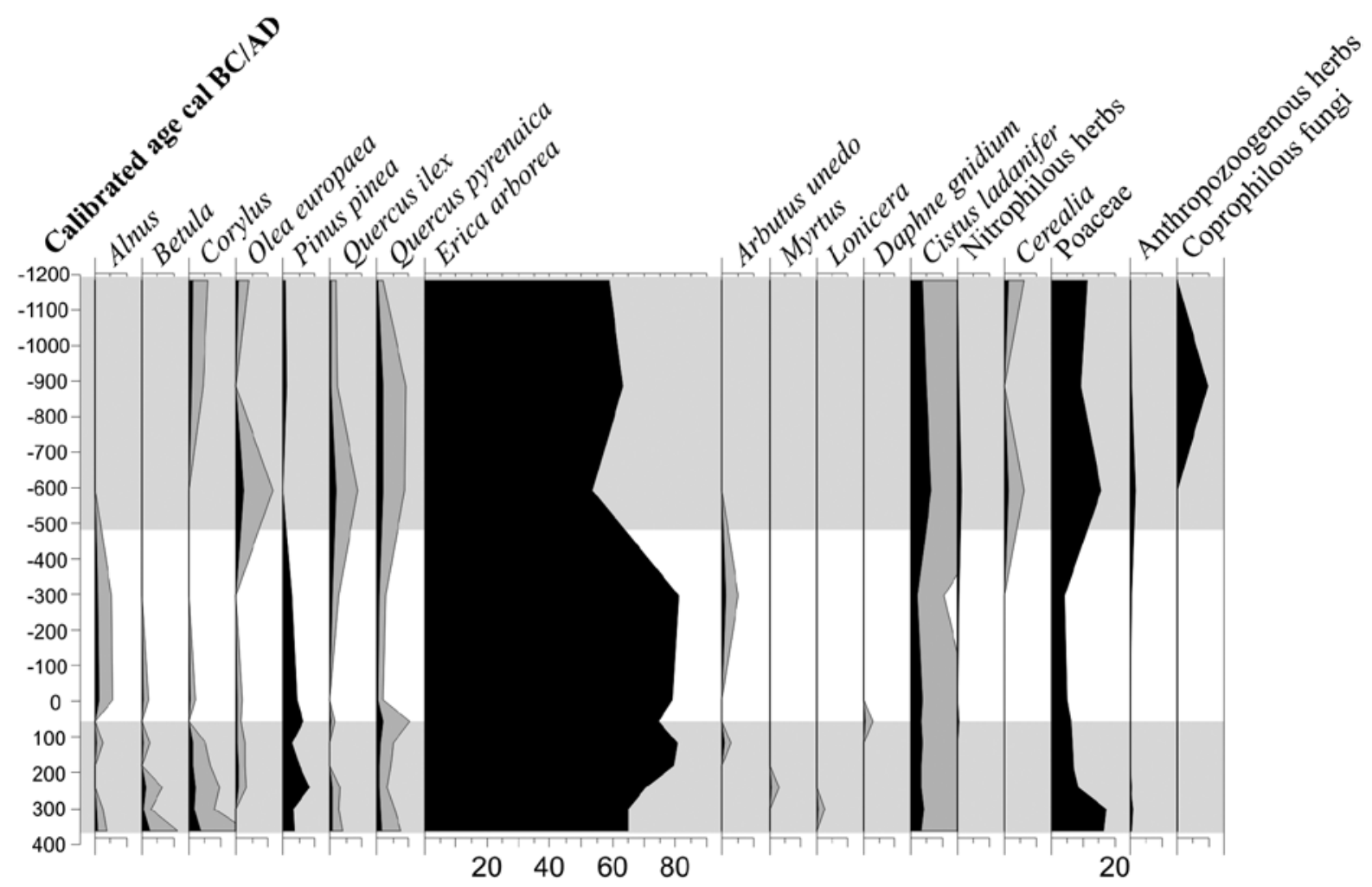

FIGURE 6 Percentage pollen diagram of Patateros peat bog (selected pollen and non-pollen palynomorph taxa). The grey bands represent the different phases described in the text.

model based on livestock grazing and small subsistence crops, managed by relatively self-sufficient peasants, in central and western areas of the Iberian Central System, in a sparsely populated land, denser on mid-altitudes than on valleys or high-altitudes. ${ }^{17}$ In the Guadarrama Range, in contrast, the settlements were mostly located in the river valleys, while in the mountains a very large number of watchtowers were built in order to guard the mountain passes. ${ }^{18}$

After this initial phase of forest recovery, forest clearance is continuous around high-altitude deposits $c a$. AD 950. This could be related to a seasonal exploitation of these areas, within a transterminant-type model. Deposits located at lower altitudes show a different pattern. Livestock intensification does not involve a broad clearance of forested areas, neither the use of fire, but a recovery of pine woods and oak forests in fact. This is possible thanks to pasture management, especially by means of irrigation in previously deforested areas, like Peña Negra or Rascafría. Fire and grazing indicators provide a bigger signal too, especially $c a$. AD 1000-1100, pointing to slightly more intense human pressure on the environment in La Meseguera in the Francia Range. Crops also improve slightly during this phase, helped by the milder climatic conditions of the Late Medieval

17 Blanco-González et al. (2009).

18 Jiménez and Rollón (1987).
Warm Episode. Olive and, to a lesser extent, sweet chestnut groves, grew in almost all sites, as did cereal crops, especially at the transition to the new millennium, as detected in Ojos Albos, where Cerealia and Secale increase their percentages.

\section{Southern Plateau (sites 33-34)}

Located in the La Mancha Plain, the Tablas de Daimiel pollen record ${ }^{19}$ comes from a core taken from a wetland area at 605 masl. Between $300 \mathrm{BC}-\mathrm{AD} 1000$ the landscape appears to be dominated by grasslands and hydro-hygrophytic taxa, while forest formations (evergreen oak woodlands and sparse Mediterranean pines) are always very scarce, with the latter even declining from $c a$. AD 950. Evidence of anthropisation is confirmed throughout the sequence, especially $c a .300$ $\mathrm{BC}-\mathrm{AD} 250$, whereas pastoral pressure is more evident ca. AD 250-1000.

The Patateros peat bog pollen record (700 masl) is located at the northern edge of the Toledo Mountains. ${ }^{20}$ This sequence is unique because throughout its temporal development, the local vegetation has always been dominated by a shrub community of: Erica arborea type, Cistus ladanifer, Myrtus, Lonicera and Daphne gnidium type (fig. 6). There is little arboreal pollen, with low

19 Gil-García et al. (2007).

20 Dorado-Valiño et al. (2014). 


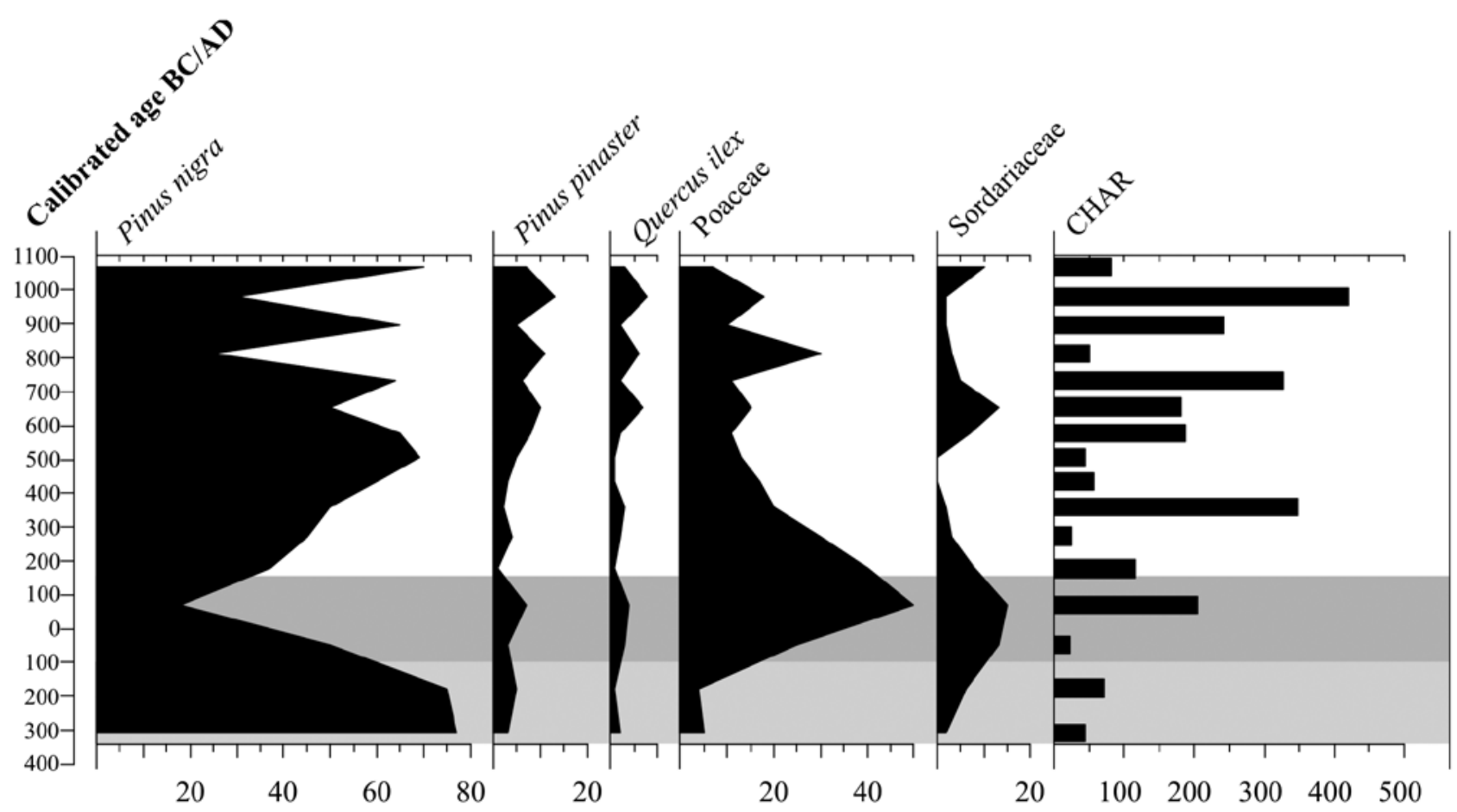

FIGURE 7 Percentage pollen diagram of Siles lake (selected pollen and non-pollen palynomorph taxa, charcoal accumulation rate-CHAR). The grey bands represent the different phases described in the text.

values of Quercus pyrenaica type, Q. ilex type and Pinus pinea type; while Corylus and Betula are only present ca. 400-50 BC. Between 50 BC-AD 1200, local vegetation shows a greater representation of Cistus ladanifer, Poaceae, and nitrophilous and anthropozoogenous herbs; Olea europaea, Cerealia and coprophilous fungi show higher values $c a$. AD 500. This suggests the development of agricultural and livestock activities in the Early Middle Ages.

\section{Southern Iberia}

\section{Baetic Mountains (sites 35-39)}

Within this study area, available palaeoenvironmental data come mainly from the south-eastern part: the Ojos de Villaverde wetland; Cañada de la Cruz and Borreguil de la Caldera peat bogs; and Siles and Gádor lakes. ${ }^{21}$ Between 400-100 BC the overall pattern of the regional landscape corresponds to high-mountain pine forests accompanied, at lower altitudes, by deciduous and evergreen Quercus, Pinus pinaster and mesophilous taxa (Betula, Corylus).

In the Ojos de Villaverde (870 masl) and Siles $(1,320$ masl) pollen records (Segura Mountains), mountain pine forests (Pinus nigra type) decrease abruptly ca. $100 \mathrm{BC}-\mathrm{AD} 150$, and Poaceae becomes dominant

21 Carrión et al. (2001a); Carrión et al. (2001b); Carrión (2002); Carrión et al. (2003); Ramos-Román et al. (2016). during the Roman period. Significantly, maximum values of Poaceae coincide with a remarkable increase in coprophilous fungi (Sordariaceae) percentages, suggesting an increase in grazing in the lakes' surroundings. These findings are associated with a recurrence of anthropogenic fires (an increase in the charcoal accumulation rate) that leads to a gradual disappearance of the forest cover (fig. 7). Later, the period AD 150-1100 is characterised by rapid alternances of Pinus nigra type and Poaceae, related to frequent fire events, anthropogenic disturbance (mainly grazing pressure) and regional aridity. The Ojos de Villaverde record points to local deforestation and the expansion of pasture plants and arable agriculture, at least from $\mathrm{AD} 35^{\circ}$, while the Siles record shows the existence of arable agriculture (Cerealia, Vitis) from AD 550. Documentary evidence is scarce, but it is clear that agricultural practices existed during the Roman period, and an important urban expansion had already taken place by the Islamic period, when the flanks of the Segura Mountains were dotted with a string of villages practising irrigation, separated by large areas of pasture. ${ }^{22}$ In the same mountain range, the Cañada de la Cruz (1,595 masl) record only begins to show evidence of human impact $c a$. AD 1000, probably indicating that economic activities were more important at lower altitudes.

Further south, in the Gádor Range, the pollen record from Gádor lake (1,530 masl) also shows the dominance

22 Carrión et al. (2001a). 
of a pine forest here until $\mathrm{AD} 330$, in a context of progressive aridity. Later, Pinus decreases, while Poaceae, Juniperus and Lygeum become more frequent, as well as Sordariaceae, Polygonum aviculare type and Riccia, suggesting a substantial increase in pastoral pressure. Microcharcoal particles are especially abundant, reaching maximum values $c a$. $150 \mathrm{BC}-\mathrm{AD} 35^{\circ}$ during the Roman period. In the Sierra Nevada Range, the pollen record from Borreguil de la Caldera (2,992 masl), unlike previous examples, and due to its location at a much higher altitude, documents the co-dominance of grassland communities and pine groves (probably Pinus sylvestris) in highland mountain areas, until 200 BC. Between $200 \mathrm{BC}-\mathrm{AD} 1000$, pine forests are progressively reduced as a result of the pastoral pressure (an increase of Sporormiella and Sordaria values), while in the valleys olive and chestnut cultivation begins.

\section{Guadalquivir Basin (site 4o)}

In the south-central area of southern Iberia, a key pollen record is available from the Zoñar lake, ${ }^{23}$ located at 300 masl in the southern margin of the Guadalquivir river basin. From AD 180-935, the regional vegetation comprised evergreen Quercus, Mediterranean pines, junipers, and some thermophilous elements, such as Olea europaea var. sylvestris, Pistacia lentiscus, Rhamnus, Lycium and Ceratonia siliqua; while local vegetation around the lake was dominated by riparian woodlands (Alnus, Fraxinus, Populus, Ulmus). High values of Myriophyllum spicatum, Botryococcus, Pediastrum and Zygnemataceae suggests high lake levels and mesoeuthrophic fresh waters. Agricultural (Cerealia) and livestock activities (Plantago lanceolata type) are attested at this time. Later, until the 11th $\mathrm{c} . \mathrm{AD}$, a growing trend in Olea indicates increasing cultivation at a regional scale, as well as around the lake; while cereal recurrence suggests a period of more intense farming during the Muslim period (AD 600-1100).

\section{Eastern Iberia}

Three high-resolution pollen records are available from the north-eastern regions of the Iberian Peninsula. The palaeoenvironmental study of the Castelló lagoon (site $41),{ }^{24}$ located at the northern border of the Empordà basin, offers significant data that characterise three

\footnotetext{
23 Valero-Garcés et al. (2006); Martín-Puertas et al. (2008); Martín-Puertas et al. (2011).

24 Ejarque et al. (2016).
}

phases of vegetation evolution and human impact in the Mediterranean coastal area. Between 1500-800 BC, Quercus suber and Q. ilex type percentages are fairly high, probably representing mesomediterranean oak forests with some pines in the vicinity of the lagoon system. This is additionally well-discriminated by the presence of thermophilous shrubs (Cistus, Erica, Olea, Pistacia) and halophytes (Chenopodiaceae) in a flooding phase of the lagoon by the sea, when archaeological settlements located in the floodplain were abandoned. A period of increasing human impact is recorded $c a$. $800-150$ BC by a new development of grazing activities (maximum values of coprophilous fungi) and the recording of Cerealia and Secale. These data suggest the local presence of arable fields and moderate human pressure during the Late Iron Age, concomitant with the clearance of evergreen and cork oak woodlands, and the exploitation of littoral wetlands under lower salinity conditions. This also coincides with increasing settlement, and the onset of cultural and commercial contacts between local populations and Phoenician and Greek cultures.

The Roman period ( $150 \mathrm{BC}-\mathrm{AD} 750$ ) appears to be a threshold phase in the landscape shaping of the coastal areas, in a gradual process of reduced marine influence with the replacement of salt vegetation by freshwater marshes, reeds and wet meadows (Cyperaceae, Poaceae). The progressive decline of tree percentages suggests woodland clearings, which are accompanied by the spread of anthropozoogenic nitrophilous grasslands and coprophilous fungi, and a more regular presence of crops (Cerealia, Secale, Castanea). This confirms increasing agropastoral exploitation around the lagoon, as a result of the intense rural occupation of this territory following Roman colonisation after the 2 nd с. вс. ${ }^{25}$ Finally, ca. AD 750-1250, agropastoral activities and the cultivation of olive trees are still documented. An important change in the vegetation composition of the Castelló record occurred $\mathrm{ca}$. AD 750, namely a large-scale and long-lasting clearance of littoral woodlands and the expansion of pasturelands. This likely indicates a replacement of cork oak forests by shrublands, dominated by Erica arborea type and Cistus. This major change in land use practices correlates with the Carolingian conquest and the pioneer settling of Christian monastic communities in the area.

The above-mentioned colonisation of the frontier zone was incited by Carolingians through the aprisio landholding system, granting ownership of undeveloped lands to new settlers through their clearance and

25 Palet et al. (2014). 


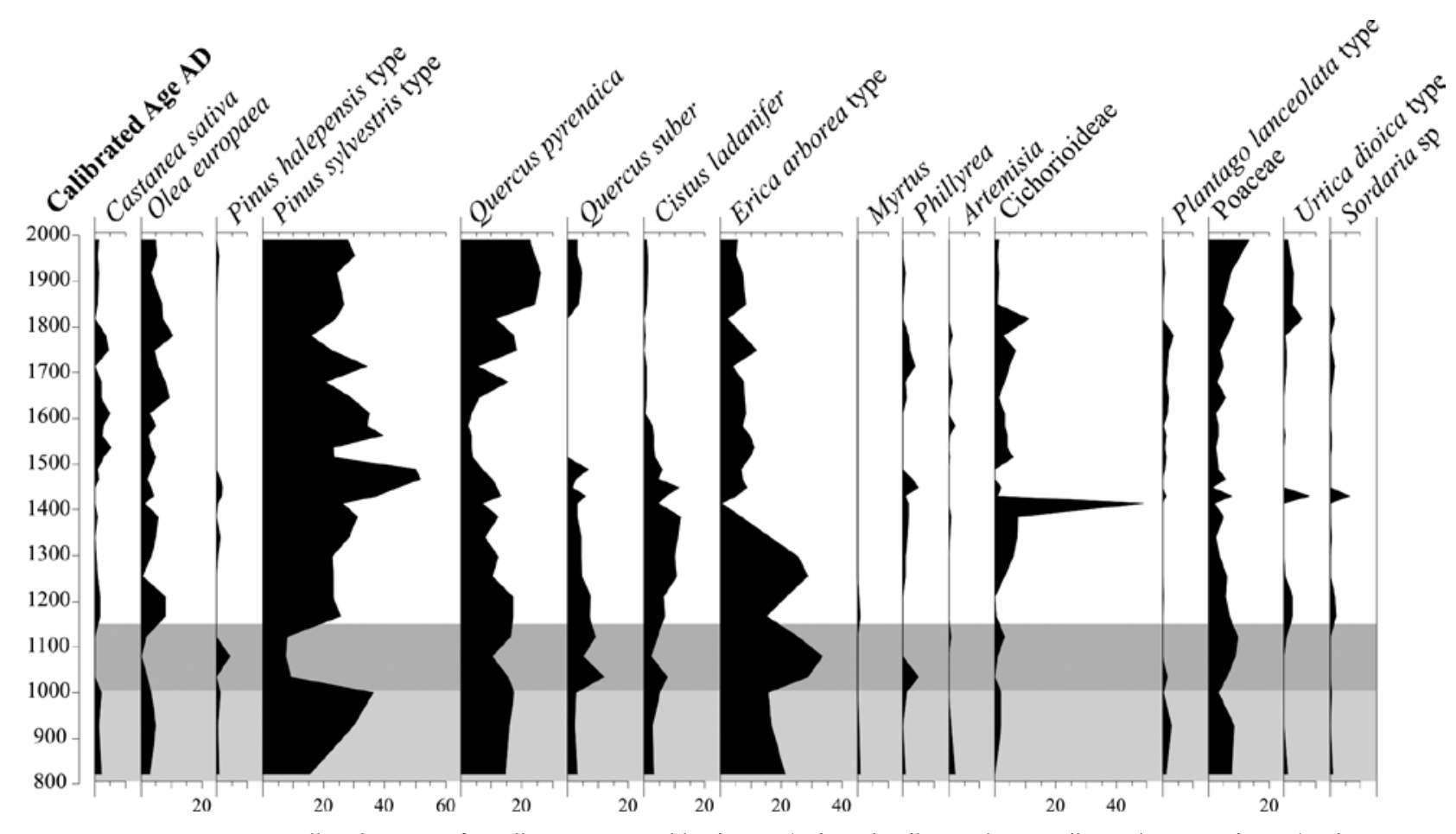

FIGURE 8 Percentage pollen diagram of Portlligat Bay peat-like deposit (selected pollen and non-pollen palynomorph taxa). The grey bands represent the different phases described in the text.

cultivation. The implementation of this system largely impacted on the Empordà basin by putting in place an generally open coastal landscape type. ${ }^{26}$ Regionally, this change is confirmed by the Sobrestany lagoon's pollen record in the lower Empordà basin (site 42), where oak woodlands were cleared after the mid 7 th c. AD. ${ }^{27}$

In north-eastern Iberia, on the Mediterranean coast (Cape Creus), a very interesting pollen sequence is that of Portlligat Bay (site 43). ${ }^{28}$ This sedimentary record is considered to be quite unusual, as it is a peat-like deposit derived from the accumulation of the below-ground dead parts of the marine phanerogam Posidonia oceanica through the last 4,500 years. Between AD 800-1000, the combined presence of Quercus pyrenaica type and Q. suber suggests a relatively open oak wood with cork oaks (fig. 8). The low percentages of Pinus halepensis type could be a sign of a short period of development of the coastal mesomediterranean pine forest in the area. At this time, chestnut tree (Castanea sativa) was cultivated. Regionally, high values of Pinus sylvestris type point to a wide development of high-mountain pinewoods around the central-eastern foothills of the Pyrenees. Shrub el-

\footnotetext{
26 Chandler (2002); Ejarque et al. (2016).

27 Parra et al. (2005).

28 López-Sáez et al. (2008); López-Sáez et al. (2009a); Serrano et al. (2011); López-Merino et al. (2015).
}

ements show a remarkable importance, with Erica arborea type and Cistus ladanifer as main taxa, as well as a xerothermophilous macchia composed of myrtles (Myrtus), Phillyrea and wild olive tree pollen seen. The presence of anthropozoogenous herbs (Urtica, Plantago lanceolata type) and coprophilous fungi (Sordaria) is indicative of significant local livestock pressure. Unlike the two above-mentioned pollen records, in the Portlligat sequence, oak woodlands remained untouched until the 11th c. AD, stressing the complexity of landscape management in north-east Iberia. During the 11th-12th c. (AD 1000-1150), a drastic deforestation of high-mountain pine forests in the eastern Pyrenees occurred; chestnut cultivation ceased, attended by a local deforestation of oak woodlands, with a resulting proliferation of heathers. These findings are related to an increase in medieval settlement in the eastern Pyrenees, probably benefiting from the mild and humid climate, associated with the Late Medieval Warm Episode. Interestingly, this population shift towards the high areas of the Pyrenees causes local pastoral pressure to disappear.

\section{Pyrenees}

The small lake of Montcortès (site 44) is especially wellsuited for high-resolution palaeoecological reconstruction due to its annually laminated sediments, which 
extend back at least 7,000 years. ${ }^{29}$ It is located on the southern flank of the central Pyrenees (1,027 masl). Its pollen record shows that the pre-feudal period (8th9th c. AD) were characterised by the presence of welldeveloped pine forests (Pinus nigra type), while crops and weeds were almost absent. An intensification of burning practices at the beginning of the feudal period, ca. AD 9oo, led to intensive clearance of woodlands and to their progressive replacement by rye (Secale) and hemp (Cannabis) cultivation, as well as by meadows and pastures. In the nearby pollen records of the Prats de Vila (1,150 masl) and Estanilles (2,247 masl) peat bogs and Redon lake (2,240 masl) (sites 48-50), a dense forest of firs (Abies alba) and pines dominated the landscape ca. $250-50$ BC. ${ }^{30}$ Later, the fir forest suffered a strong regression from $50 \mathrm{BC}$, derived from the selective use of its wood in metallurgical activities, particularly during the $3^{\text {rd }}$ and 4th c. AD, coinciding with the occasional presence of Juglans and Cerealia, although the pine forest remained relatively stable. Between AD 650-1150, pine and fir forests suffered a strong regression, related to the extension of chestnut and cereal crops, as well as a high pastoral pressure.

Further south, in the Pre-Pyrenees, the palaeoenvironmental record (site 47) from Estanya lake ${ }^{31}$ (670 masl) shows a relatively forested and well-preserved landscape of deciduous and evergreen Quercus, where Mediterranean pines were also an important element ca. 500 BC-AD 750 (Late Roman and Visigothic era). Cultivated taxa (Olea europaea, Vitis, Cerealia, Cannabis) are abundant, although the presence of nitrophilous plants is still very small, suggesting that stockbreeding and grazing were less developed. The highest values of Cerealia pollen are found $c a .50 \mathrm{BC}$, coinciding with the Roman period. In contrast, a lower-degree of anthropogenic impact is recorded at the highland locations of the central Pyrenees. Not even the Redon or Basa de la $\operatorname{Mora}^{32}$ (1,914 masl) lacustrine sequences (sites 50-51) show cultivation, stockbreeding or deforestation signals during this period, as at Estanilles (site 49). Forests were slightly reduced by means of fire $c a$. AD 750-1000 in the Estanya record (site 47), coinciding with the introduction of new crops (Juglans, Secale) during the Muslim period. Human deforestation processes have been also recognised at higher altitude in the above-mentioned

\footnotetext{
29 Corella et al. (2011); Rull et al. (2011); Rull and Vegas-Villarrúbia (2014); Rull and Vegas-Villarrúbia (2015).

30 Pèlachs et al. (2009); Pérez-Obiol et al. (2012); GonzálezSampériz et al. (2017).

31 Riera et al. (2004); Riera et al. (2006); Morellón et al. (2008); Morellón et al. (2009); Morellón et al. (2011); GonzálezSampériz et al. (2017).

32 Pérez-Sánz et al. (2011); Pérez-Sánz et al. (2013).
}

Estanilles and Redon records from AD 750, although this phase is not clearly identified in the Basa de la Mora sequence (sites 49-51).

At high-altitude sites on the northern flank of the central Pyrenees, ${ }^{33}$ the pollen records from the Pla de Labinas (1,80o masl), Orri de Théo (1,640 masl) and Pla de Soulcem $\left(1,520\right.$ masl) peat bogs (sites $45^{-46,60}$ ) show a well-developed pine-fir forest during the Iron Age, accompanied by birches, hazel and beech. Although the anthropic use of fire is attested, its incidence in the forests was scarce. From the Gallo-Roman period ( $c a .50$ $\mathrm{BC}-\mathrm{AD} 400)$, an increase in human impact is recorded by a pronounced decline in pine cover and the increase of heliophilous species, such as birch and beech, and grasslands. This process is even more evident during the second half of the Early Middle Ages $c a$. AD 400-1000, when the presence of cereal pollen is attested. The same dynamics is observed at lower altitude in the Pélissié (312 masl) and Col d'Ech (710 masl) pollen records (sites $52-53),{ }^{34}$ although with a greater amount of deciduous oak and beech forests; whereas the cultivation of cereals is attested from $\mathrm{AD} 250$ and that of rye from $\mathrm{AD} 700$. In the eastern Pyrenees, the Pla de l'Orri (2,105 masl) and Pradell (1,975 masl) sequences (sites 54-55) follow the same pattern mentioned above, for sites located at high altitude in the central Pyrenees. ${ }^{35}$

In the western Pyrenees, pollen records from the Gabarn (310 masl), Quinto Real (910 masl), Artxilondo (950 masl) and Sourzay (1130 masl) peat bogs (sites $56-59),{ }^{36}$ show the existence of well-preserved oak and beech forests during much of the Iron Age, witnessing the cultivation of cereal in the valley areas. The end of the Iron Age and antiquity ( $c a .150 \mathrm{BC}-\mathrm{AD} 400)$ is reflected in a spatial extension of anthropogenic activities, including woodland clearances, grazing pressure, pastureland development and anthropic fire episodes, as well as metallurgical activities (fig. 9). The steady level of Cerealia pollen suggests that this increase in human impact occurred at a greater scale. During the Middle Ages (ca. AD 400-1000) the fire regime is characterised by high fire frequencies, and a diversification in cultivated crops (the first occurrences of Secale), and by the expansion of husbandry activities to their greatest extent.

\footnotetext{
33 Galop and Jalut (1994).

34 Rius et al. (2012); Cunill et al. (2015).

35 Vannière et al. (2001); Ejarque et al. (2009).

36 Galop et al. (2001); Galop et al. (2002); Monna et al. (2004); Galop (2005); Jouffroy-Bapicot et al. (2007); Mazier et al. (2009); Rius et al. (2009); Pérez-Díaz et al. (2015).
} 


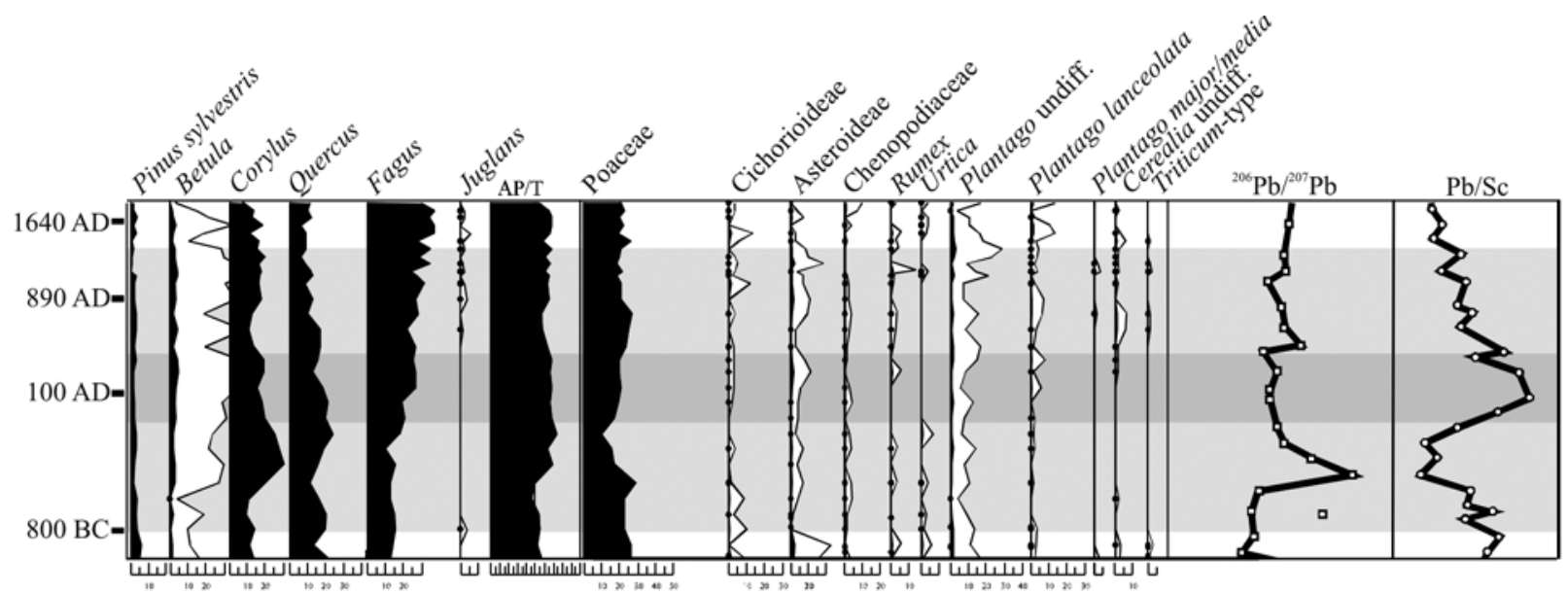

FIGURE 9 Percentage pollen diagram of Quinto Real peat bog (selected pollen taxa) with $\mathrm{Pb} / \mathrm{Sc}$ and ${ }^{206} \mathrm{~Pb} /{ }^{207} \mathrm{~Pb}$ ratios reflecting historical mining activities. The grey bands represent the different phases described in the text.

\section{South-Eastern France}

Only two high-resolution pollen records are available from this region. The first one comes from the Palavas lagoon (site 61), located in the Languedoc under both Mediterranean and Atlantic climatic influences. ${ }^{37}$ Between ca. 500-100 BC, trees dominate the pollen spectra, mainly comprising deciduous and evergreen Quercus, associated with Pinus; Juglans, Vitis and Cerealia are recorded sporadically during the Late Iron Age (fig. 10). Later, $c a .100 \mathrm{BC}-\mathrm{AD} 600$, forest formations were gradually degraded, while bushes (Ericaceae) increased, with a continuation of olive cultivation throughout the period. These findings can be explained by taking into account settlement migration from the hinterland to the coastal areas; most villae were located in coastal plains. Finally, ca. AD 650-750, deciduous Quercus forest recovery appears to be occurring in the transition to the Early Middle Ages, coinciding with a gap in the archaeological record. Although later, $c a$. AD 800-1000, such forest is reduced again, coinciding with greater agricultural and livestock activity (maxima of Olea and Plantago; presence of Juglans, Castanea, Vitis and Cerealia) and an evergreen shrubland extension, pointing to a strong human influence on the environment during the High Middle Ages.

To the east of the Palavas lagoon, the La Calade record (site 62) comes from a wetland located in the lower Rhône floodplain (4 masl). ${ }^{38}$ In a first phase, corresponding to the period of Greek presence at Marseille and to the Roman empire in Provence, the sequence shows a similar vegetation pattern to that seen in Palavas ca. $500 \mathrm{BC}-\mathrm{AD} 600$. That is a dominance of oak woodland with Mediterranean pines, which are gradually reduced; and a cultivation of walnut, chestnut, olive, grape and cereals including rye. Cattle breeding was also practised locally, as inferred by the presence of anthropozoogenous taxa (Chenopodiaceae, Plantago lanceolata type, Polygonum aviculare type). During a second phase, forest cover recovers in the Merovingian period; although it quickly degrades again in a third phase. This is as a result of a very high pastoral pressure during the High Middle Ages, while cereals and rye are still cultivated, but with greater intensity. This phase could be related to the establishment of a monastic community (Montmajour Abbey, mid-gth c.) and to an increasing number of farmers in the surrounding area.

\section{North-Western Africa}

\section{Rif Mountains (sites 63-66)}

Pollen records from this region show the dominance of cedar (Cedrus atlantica) and mirbeck's oak (Quercus canariensis, Q. pyrenaica) forests ca. $1000 \mathrm{BC}-\mathrm{AD} 400$, likely related to increasing moisture, suggested by the general sharp increase of hydro-hygrophytic taxa. This picture is confirmed by several pollen records in the western Rif Mountains (fig. 11):39 Maison Forestière (1,602 masl) and Dayet M'Had (754 masl) in the Jbel Bou Hachen (sites 65-66); Aanasser (1,342 masl) in the Jbel Tizirène (site 64); and Fifi (1,200 masl) in the Jbel Khesana (site 63). At this time, agricultural activities (Cerealia, Vicia faba type) are attested. It seems that anthropogenic activities (fire and grazing) during the Phoenician

39 Cheddadi et al. (2015); Muller et al. (2015); Abel-Schaad et al. (2016). 


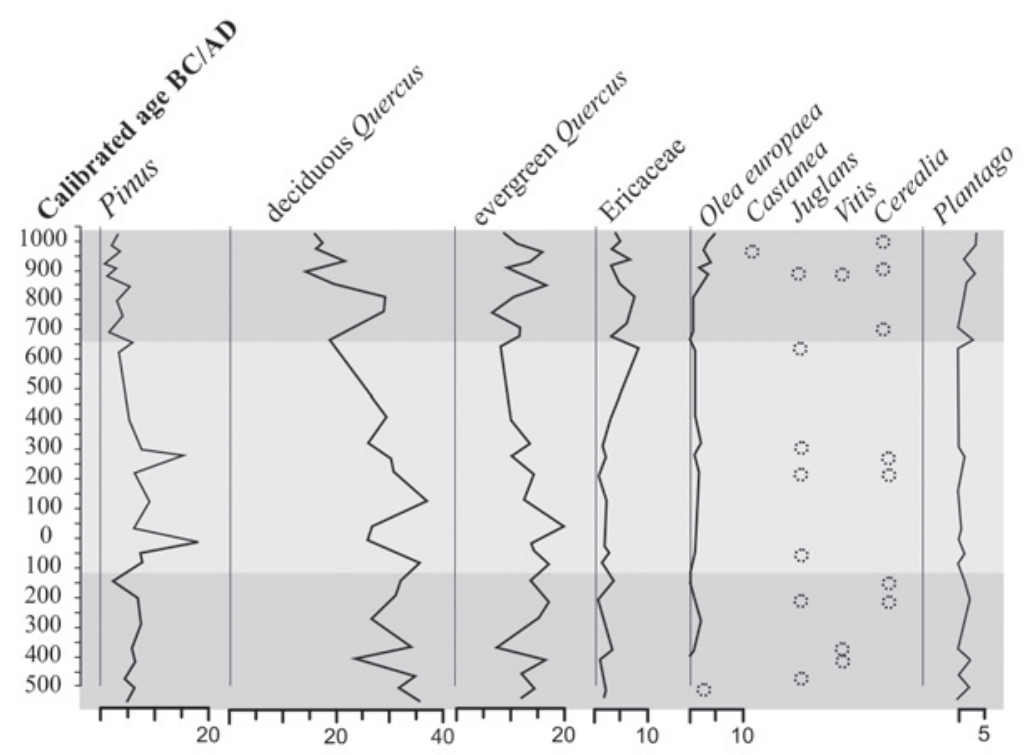

FIGURE 10 Percentage pollen diagram of Palavas lagoon (selected pollen taxa). The grey bands represent the different phases described in the text.

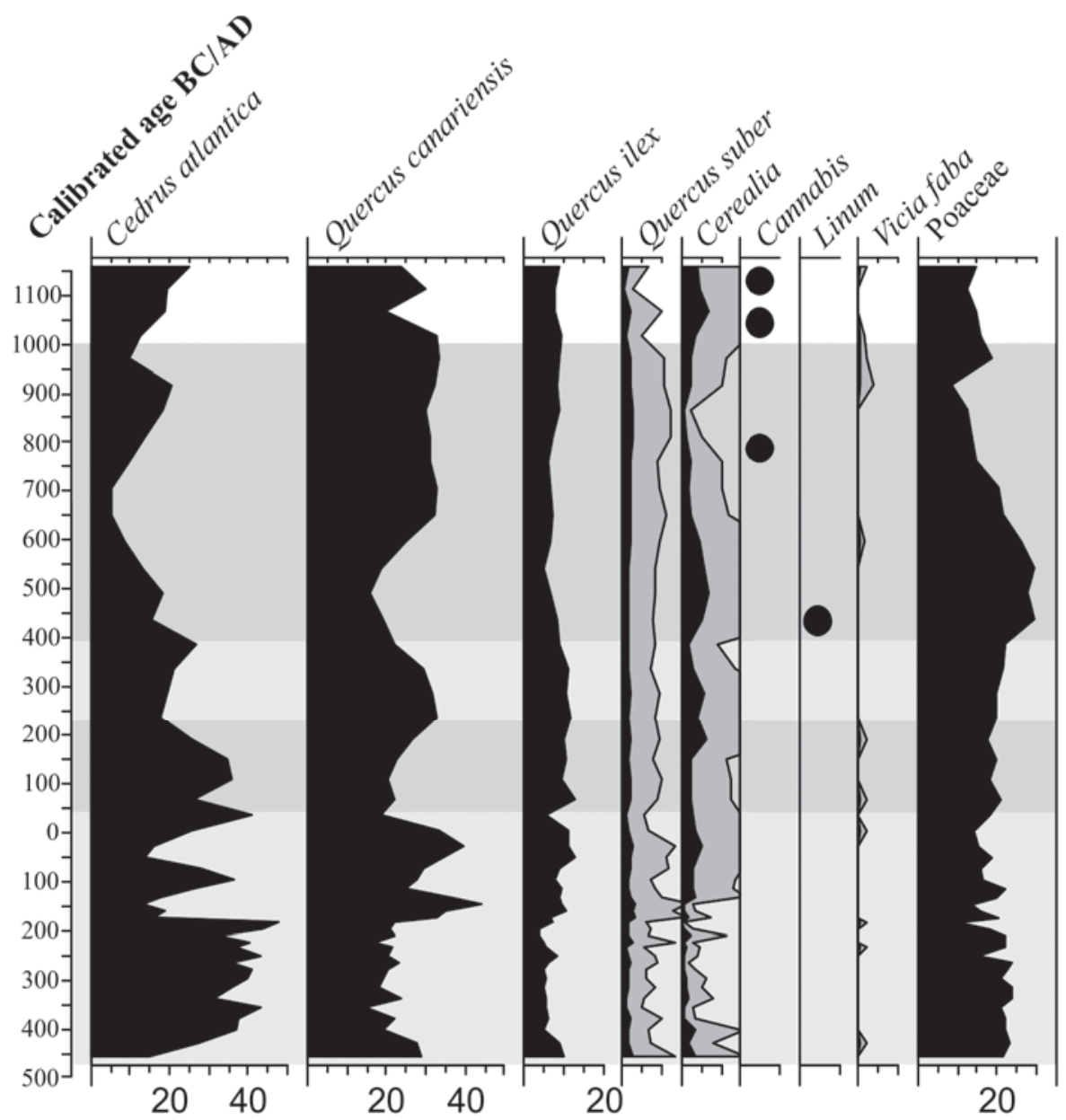

FIGURE 11 Percentage pollen diagram of Fifi wetland (selected pollen and non-pollen palynomorph taxa). The grey bands represent the different phases described in the text. 
period $c a .1000 \mathrm{BC}-\mathrm{AD} 50$ did not impact greatly on a well-developed mirbeck's oak-cedar forest.

The further clearance of Quercus canariensis forests $c a$. AD 50 coincides with the development of cork oak and holm oak woodlands (Quercus suber, Q. ilex) at lower altitudes, and with the beginning of cedar decline. This period corresponds to the Roman colonisation of northern Morocco, and to the foundation of the Roman province of Mauretania Tingitana (AD 40). The area of modern day Morocco remained a part of the Roman empire until AD 429, when Vandals displaced Romans. After $c a$. AD 500, the Rif remained occupied by the indigenous Berber inhabitants and the Byzantines, until the arrival of the Arabs in AD 681. This set of events gave rise to a remarkable phase of deforestation, which took place in the western Rif Mountains ca. AD 400-700, carried out by fire, leading forest levels to their minima, while grasslands and shrublands spread. Later, $c a$. AD 700-1000, humid conditions, shown by a rise in aquatic taxa, allowed forests to recover, especially Quercus canariensis/pyrenaica and Q. suber ones, while Cedrus always remained at a significant percentage. The absence of coprophilous fungi points to scarce grazing activity. Cereal and bean cultivation continued, with the first occurrences of Linum (AD 400) and Cannabis (AD 750). At later dates (AD 900-1300), the cedar progressively declined, until it disappears in the Maison Forestière sequence $c a$. AD 1050.

\section{Middle Atlas Mountains (sites 67-7o)}

Four high-resolution pollen records are available from lakes located in this area, ${ }^{40}$ in the present-day cedar-holm oak woodland. These are Taguelmam n'Harcha $(1,640$ masl), Tigalmamine (1,626 masl), Tifounassine (1,913 masl) and Sidi Ali (2,08o masl). At Tigalmamine, before 200 BC, pollen spectra are dominated by the Quercus ilex type, Cedrus atlantica and Poaceae. However, from that date on, a slow decline in forest formations began, parallel to a greater abundance of anthropozoogenous herbs, showing that pastoral pressure was responsible for such a decline. At Taguelmam n'Harcha, forest clearance and grazing became more intense $c a$. AD 300, when the presence of cultivated cereals is detected. At Sidi Ali and Tifounassine there is some weak evidence for human impact $c a .1000 \mathrm{BC}$, but it seems that anthropogenic processes became evident only $c a$. 400-200 BC. This evidence for landscape anthropisation results from the Roman expansion into the Middle Atlas, as Roman populations settled the town of Volubilis, near Meknes.

$40 \quad$ Lamb et al. (1989); Lamb et al. (1991); Lamb and van der Kaars (1995); Lamb et al. (1999); Cheddadi et al. (2015).

\section{Discussion and Conclusions}

Palynological investigations of human impact in the mountains of north-western Morocco suggest that human use of forest resources was less drastic prior to the expansion of the Roman empire. However, pollen data show a regression of forest taxa $c a .200$ в in the Middle Atlas and $c a$. AD 50 in the Rif Mountains, which suggests an increase in the human use of high-altitude forests from the Roman period. The contemporaneous vegetation disturbances recorded in the Middle Atlas and the Rif Mountains resulted from large-scale anthropogenic forest disturbances, which nevertheless appear very weak in comparison to those occurring at the same time in south-western Europe. Indeed, the activities of Roman/Romanised populations triggered, almost everywhere in south-western Europe, dramatic deforestations, accompanied by severe ecosystem modifications. ${ }^{41}$ In the south-east of Iberia, several records from the Baetic Mountains demonstrate the millennial persistence of pine forests until $100 \mathrm{BC}$, as well as a drastic deforestation of these during the Roman period $c a$. $100 \mathrm{BC}-\mathrm{AD} 150$, linked to an increase in pastoral pressure and the occurrence of anthropic fires. A progressive decline in tree cover during the Roman period has also been documented in the northern Iberian plateau and south-eastern France.

In the Iberian Central System, at the time of the Late Iron Age ( $c a .400-50 \mathrm{BC})$, anthropic dynamics had different impacts on each mountain range considered here. Within the Vettonian region, forests are well-developed both in highland and lowland areas. Within the Carpetanian region, high-mountain forests are also welldeveloped, but the lowlands, especially easternmost ones, evidence a phase of socio-cultural change. This is shown by an increase in the number of settlements, territorial reorganisation and new land use systems, resulting in a deforested landscape with evidence for both grazing and farming activities. During the Roman period (ca. $50 \mathrm{BC}-\mathrm{AD} 45^{\circ}$ ), large-scale deforestations resulted in open landscapes characterising lowland areas, as a consequence of the intensification of human activities, like cropping, grazing, mining or forestry. However, anthropogenic dynamics in the highlands was different in each area of the massif, and was connected to mining (western areas) or greater settlement (eastern areas), while the Gredos Range (central area) was hardly altered at all, due to its inaccessibility.

The decline of western Mediterranean forests, although initiated during the Roman era, really began several centuries later. In the Baetic Mountains, from

41

41 López-García (1994); De Beaulieu et al. (2005); Blondel (2006). 
the Roman period until the 1oth c. AD, the vegetation shows an alternating dynamic, related to livestock activities and fire events. Evidence of agriculture is initially detected $c a$. AD $35^{\circ}$ at low altitude, and then at higher altitude $c a$. AD 550. At higher altitudes, human impact is only evident from $c a$. $\mathrm{AD} 1000$. In the north-eastern regions of Iberia, from the Iron Age to the end of the ancient period ( $1500 \mathrm{BC}-\mathrm{AD} 75^{\circ}$ ) human settlement and agropastoral exploitation of wetland ecosystems responded to natural coastal dynamics.

During this period, human land uses produced a limited impact on the lagoon landscapes, that were dominated by evergreen and cork oak woodlands. In contrast, societies become a major agent of landscape transformation $c a$. AD 750-1250, actively controlling the lagoon dynamics and resources. Evidence for this can be seen in the degradation of coastal forests and the expansion of agricultural and livestock activities from the 8th c. AD. In the lowlands of the southern Pyrenees, pollen records show a strong deforestation phase of the pine forest from $\mathrm{AD}$ 90o, linked to the cultivation of hemp and rye. Pollen data from south-eastern France show a period of widespread deforestation at the beginning of the Middle Ages ca. AD 800-1000, after an earlier, limited recovery of the forest $c a$. AD $65^{0}-75^{\circ}$. In the Rif Mountains, pollen records suggest significant deforestation $c a$. AD 400-700 during the period of Byzantine dominance. The disappearance of evergreen oak woodlands on the northern Iberian plateau is attested $c a$. AD 400. Deforestation during the Germanic era, also represented a tipping point in the history of mesophilous forests in the northern Iberian mountains $c a$. AD 450-700. In the lowlands of the Cantabrian Range, the Middle Ages led to the onset of a gradual but permanent deforestation. Previously forested areas in northern Iberia were occupied by heathlands and grasslands.

At the beginning of the Middle Ages, the intensity of human impact on the environment increased notably ca. AD 450-700 after the collapse of the Roman system in the Iberian Central System and the Toledo Mountains. This is documented by large deforestation processes at high altitudes, and by a rise in anthropogenic pollen indicators. This is within a clear livestock-oriented pattern, although new lands were brought into cultivation with the onset of the Early Medieval Cold Episode (AD 450-950). An initial phase of forest recovery (birch, alder and deciduous oaks in western areas; pine in central and eastern areas) is recorded in high-mountain environments from AD 700-950, as a result of a decline in livestock and farming activities, while agropastoral pressure increases at low altitudes. Then a new phase of forest clearance takes place $c a$. AD 950-1100, related to transterminant movements and the milder weather conditions of the Late Medieval Warm Episode (AD
950-1350). In the lowlands, livestock intensification did not involve a broad clearance of forested areas, only some diversification in crops.

Landscape clearance after $c a$. 150 BC-AD 300 does not have to be primarily determined by increased human impact; a climatic explanation is also plausible. In fact, pollen data from the Baetic Range document an increasing trend in dryness from the Mid Holocene, as shown by the progressive decrease in tree species (mainly pines) and the increase in xerophytes, such as Artemisia. The semi-desert expansion and high-mountain forest decline during the Late Holocene in southern Iberia could be also explained by decreasing summer insolation. ${ }^{42}$ One of the most conspicuous features of the Zoñar pollen record is the succession of wet and dry conditions at a centennial-scale, generally synchronous with rapid climate changes that occurred in the Mediterranean basin during the Late Holocene. Arid phases are identified prior to $95^{\circ} \mathrm{BC}$, in the Roman period from $15^{\circ}$ BC-AD 150, and AD 800-1300. ${ }^{43}$ The second phase coincides with documented deforestation processes in the Gádor, Segura and Sierra Nevada ranges, mediated by a higher incidence of forest fires. More humid conditions occurred $c a$. AD 150-350 during the later Roman empire. This period coincides with a recovery in high mountain pine forests throughout the whole of the Baetic Mountains, as well as with the first evidence for agriculture there.

It is interesting to note that the most important recorded landscape changes in the western Mediterranean region coincide with the lower temperatures and greater aridity of the Early Medieval Cold Episode (AD 500-900); although such changes are even more evident with the onset of the Medieval Climate Anomaly (MCA) (AD 9001350). ${ }^{44}$ In Mediterranean Iberia, the MCA was a period characterised by decreased lake levels, more xerophytic and heliophytic vegetation (Juniperus, Artemisia), and a low frequency of floods, suggesting warmer yet still arid conditions. ${ }^{45}$

\section{Acknowledgements}

The research presented in this paper was funded by the following projects: Desirè-HAR2013-43701-P (Plan Nacional I+D+I, Spanish Ministry of Economy

\footnotetext{
42 Jiménez-Moreno et al. (2015).

43 Martín-Puertas et al. (2010); Martín-Puertas et al. (2011).

44 Morellón et al. (2011); Morellón et al. (2012); Blanco-González et al. (2015).

45 Morellón et al. (2012); Moreno et al. (2012); Roberts et al. (2012); González-Sampériz et al. (2017).
} 
and Competitiveness); and Relic-Flora-P11-RNM-7033 (Excellence Research Projects Program from the Andalusian Government).

\section{Bibliography}

Abel-Schaad D. and López-Sáez J. A. (2013) “Vegetation changes in relation to fire history and human activities at the Peña Negra mire (Bejar Range, Iberian Central Mountain System, Spain) during the past 4.000 years", Vegetation History and Archaeobotany 22 (2013) 199-214.

Abel-Schaad D. et al. (2016) "Declive de los bosques de cedro (Cedrus atlantica) durante el Holoceno reciente en el sector occidental de la cordillera del Rif (Marruecos)", in Avances en Biogeografía: áreas de distribución: entre puentes y barreras, edd. J. Gómez, J. Arias, J. A. Olmedo and J. L. Serrano (Granada 2016) 592-6oo.

Abel-Schaad D. et al. (2014) "Heathlands, fire and grazing. A paleoenvironmental view of Las Hurdes (Cáceres, Spain) history during the last 1200 years", Forest Systems 23 (2014) $247-58$.

Abel-Schaad D. et al. (2009) "Evolución de la vegetación en la Sierra de Gata (Cáceres-Salamanca, España) durante el Holoceno reciente. Implicaciones biogeográficas", Revista Española de Micropaleontología 41 (2009) 91-105.

Andrieu-Ponel V. et al. (2000) "Palaeoenvironments and cultural landscapes of the last 2000 years reconstructed from pollen and coleopteran records in the Lower Rhône Valley, southern France", The Holocene 10 (2000) 341-55.

Azuara J. et al. (2015) "Late Holocene vegetation changes in relation with climate fluctuations and human activity in Languedoc (southern France)", Climate of the Past 11 (2015) 1769-84.

Blaauw M. (2010) "Methods and code for classical age-modelling of radiocarbon sequences", Quaternary Geochronology 5 (2010) 512-18.

Blanco-González A. et al. (2015) "Medieval landscapes in the Spanish Central System (450-1350): a palaeoenvironmental and historical perspective", Journal of Medieval Iberian Studies 7 (2015) 1-17.

Blanco-González A. et al. (2009) “Ocupación y uso del territorio en el sector centromeridional de la Cuenca del Duero entre la Antigüedad y la Alta Edad Media (siglos I-XI d.C.)", Archivo Español de Arqueología 82 (2009) 275-300.

Blondel J. (2006) “The 'design' of Mediterranean landscapes: a millennial story of humans and ecological systems during the historic period", Human Ecology 34 (2006) 713-29.

Carrión J. S. (2002) "Patterns and processes of Late Quaternary environmental change in a montane region of southwestern Europe", Quaternary Science Reviews 21 (2002) 2047-66.

Carrión J. S. et al. (2015) Cinco millones de años de cambio florístico y vegetal en la Península Ibérica e Islas Baleares (Murcia 2015).
Carrión J. S. et al. (2012) Paleofloray paleovegetación de la Península Ibérica e Islas Baleares: Plioceno-Cuaternario (Madrid 2012).

Carrión J. S. et al. (2010) "Expected trends and surprises in the Late Glacial and Holocene vegetation history of the Iberian Peninsula and Balearic Islands", Review of Palaeobotany and Palynology 162 (2010) 458-75.

Carrión J. S. et al. (2003) "Holocene vegetation dynamics, fire and grazing in the Sierra de Gádor, southern Spain", The Holocene 13 (2003) 839-49.

Carrión J. S. et al. (2001a) "Abrupt vegetation changes in the Segura Mountains of southern Spain throughout the Holocene", Journal of Ecology 89 (2001) 783-97.

Carrión J. S. et al. (2001b) "Crossing forest thresholds: inertia and collapse in a Holocene sequence from south-central Spain”, The Holocene 11 (2001) 635-53.

Chandler C. J. (2002) "Between court and counts: Carolingian Catalonia and the aprisio grant, 778-897", Early Medieval Europe 11 (2002) 19-44.

Cheddadi R. et al. (2015) "A history of human impact of Moroccan mountain landscapes", African Archaeological Review 32 (2015) 233-48.

Corella J. P. et al. (2013) "A 2500-year multi-proxy reconstruction of climate change and human activities in northern Spain: the Lake Arreo record", Palaeogeography, Palaeoclimatology, Palaeoecology 386 (2013) 555-68.

Corella J. P. et al. (2011) "Climate and human impact on a meromictic lake during the last 6,00o years (Montcortès lake, central Pyrenees, Spain)", Journal of Paleolimnology 46 (2011) 351-67.

Cunill R. et al. (2015) "Paleoecological study of Pyrenean lowland fir forests: exploring Mid-Late Holocene history of Abies alba in Montbrun (Ariège, France)", Quaternary International 366 (2015) 37-50.

Currás A. et al. (2012) "Climate change and human impact in central Spain during Roman times: high-resolution multiproxy analysis of a tufa lake record (Somolinos, 1280 masl)", Catena 89 (2012) 31-53.

Dearing J. A. et al. (2015) "Socio-ecological systems in the Anthropocene: the need for integrating social and biophysical records at regional scales", The Anthropocene Review 2 (2015) 220-46.

De Beaulieu J. L. et al. (2005) "Vegetation dynamics in north-western Mediterranean regions: instability of the Mediterranean bioclimate", Plant Biosystems 139 (2005) $114-26$.

Dorado-Valiño M. et al. (2014) "Contributions to the European Pollen Database. 21. Patateros, Toledo Mountains (central Spain)", Grana 53 (2014) 171-73.

Ejarque A. et al. (2016) "Coastal evolution in a Mediterranean microtidal zone: Mid to Late Holocene natural dynamics and human management of the Castelló Lagoon, NE Spain", PLoS ONE 11 (2016) e0155446: http://dx.doi.org/10.1371/jour nal.pone.0155446 (last accessed March 2017). 
Ejarque A. et al. (2009) "Tracing the history of highland human management in the eastern Pre-Pyrenees: an interdisciplinary palaeoenvironmental study at the Pradell fen, Spain", The Holocene 19 (2009) 1241-55.

Fletcher W. J. and Zielhofer C. (2013) "Fragility of western Mediterranean landscapes during Holocene rapid climate changes", Catena 103 (2013) 16-29.

Galop D. (2005) "La conquête de la montagne pyrénéenne au Néolithique. Chronologie, rythmes et transformations des paysages à partir des données polliniques", in Populations néolithiques et environnement, ed. J. Guilaine (Paris 2005) $279-85$.

Galop D. and Jalut G. (1994) "Differential human impact and vegetation history in two adjacent Pyrenean valleys in the Ariège basin, southern France, from 3000 B.P. to the present", Vegetation History and Archaeobotany 3 (1994) 225-44.

Galop D. et al. (2002) "Métallurgie et histoire de l'environnement au cours des cinq derniers millénaires en pays Basque nord (Vallée de Baigorri, Pyrénées Atlantiques, France): résultats préliminaires d'une approche interdisciplinaire", Archeologia Postmedievale 6 (2002) 155-69.

Galop D. et al. (2001) "Cinq millénaires de métallurgie en montagne Basque. Les apports d'une démarche intégrée alliant palynologie et géochimie isotopique du plomb", SudOuest Européen 11 (2001) 3-15.

Giesecke T. et al. (2011) "The pace of Holocene vegetation change - testing for synchronous developments", Quaternary Science Reviews 30 (2011) 2805-14.

Gil-García M. J. et al. (2007) "Late Holocene environments in Las Tablas de Daimiel (south-central Iberian península, Spain)", Vegetation History and Archaeobotany 16 (2007) 241-50.

Gil-Romera G. et al. (2010) "Interpreting resilience through long-term ecology: potential insights in western Mediterranean landscapes", The Open Ecology Journal 3 (2010) 43-53.

Gómez-González C. et al. (2009) "Evolución del paisaje vegetal durante los últimos 1.68o años BP en el Macizo de Peñalara (Sierra de Guadarrama, Madrid)", Revista Española de Micropaleontología 41 (2009) 75-89.

González-Pellejero R. et al. (2014) "Dinámicas naturales y antrópicas en los paisajes vegetales de los valles internos de Cantabria occidental (norte de España)", Boletín de la Asociación de Geógrafos Españoles 65 (2014) 139-65.

González-Sampériz P. et al. (2017) "Environmental and climate change in the southern central Pyrenees since the Last Glacial Maximum: a view from the lake records", Catena 149 (2017) 668-88.

Hernández-Beloqui B. (2011) "La palinología aplicada al estudio de contextos de cronología medieval en la península Ibérica: estado de la cuestión", Revista Arkeogazte 1 (2011) 97-124.

Hernández-Beloqui B. et al. (2015) "The Late Holocene in the western Pyrenees: a critical review of the current situation of palaeopalynological research", Quaternary International $364(2015) 78-85$.
Jiménez J. and Rollón A. (1987) Guía de los castillos de Madrid (Madrid 1987).

Jiménez-Moreno G. et al. (2015) "Impact of Late-Holocene aridification trend, climate variability and geodynamic control on the environment from a coastal area in SW Spain", The Holocene 25 (2015) 607-17.

Jouffroy-Bapicot et al. (2007) "Environmental impact of early palaeometallurgy: pollen and geochemical analysis", Vegetation History and Archaeobotany 16 (2007) 251-58.

Lamb H. F. and van der Kaars S. (1995) "Vegetation response to Holocene climatic change: pollen and palaeolimnological data from the Middle Atlas, Morocco", The Holocene 5 (1995) 400-408.

Lamb H. F. et al. (1999) "Lake evolution in a semi-arid montane environment: responses to catchment change and hydroclimatic variation", Journal of Paleolimnology 21 (1999) 325-43.

Lamb H. F. et al. (1991) "Human impact on the vegetation of the Middle Atlas, Morocco, during the last 5000 years", Journal of Biogeography 18 (1991) 519-32.

Lamb H. F. et al. (1989) "An 18,000-year record of vegetation, lake-level and climatic change from Tigalmamine, Middle Atlas, Morocco", Journal of Biogeography 16 (1989) 65-74.

López-García P. (1994) "Forest, forest clearance and open land during the time of the Roman empire in Spain", European Palaeoclimate and Man 5 (1994) 23-35.

López-Merino L. et al. (2015) "Glomalin accumulated in seagrass sediments reveals past alterations in soil quality due to land-use change", Global and Planetary Change 133 (2015) 87-95.

López-Merino L. et al. (2014) "Reconstructing the impact of human activities in a NW Iberian Roman mining landscape for the last 2500 years", JAS 50 (2014) 208-18.

López-Merino L. et al. (2011) "Human-induced changes on wetlands: a study case from NW Iberia”, Quaternary Science Reviews 30 (2011) 2745-54.

López-Merino L. et al. (2010) "Early agriculture and palaeoenvironmental history in the north of the Iberian Peninsula: a multi-proxy analysis of the Monte Areo mire (Asturias, Spain)", JAS 37 (2010) 1978-88.

López-Merino L. et al. (2009a) "Estudio polínico de una laguna endorreica en Almenara de Adaja (Valladolid, Meseta Norte): cambios ambientales y actividad humana durante los últimos 2.800 años", Revista Española de Micropaleontología 41 (2009) 333-47.

López-Merino L. et al. (2009b) "200o years of pastoralism and fire shaping high-altitude vegetation of Sierra de Gredos in central Spain", Review of Palaeobotany and Palynology 158 (2009) 42-51.

López-Sáez J. A. et al. (2017a) "Una perspectiva paleoambiental de la explotación de la sal en las Lagunas de Villafáfila (Tierra de Campos, Zamora)", Cuaternario y Geomorfología (forthcoming).

López-Sáez J. A. et al. (2017b) "Unraveling the naturalness of sweet chestnut forests (Castanea sativa Mill.) in central Spain", Vegetation History and Archaeobotany 26 (2017) 167-82. 
López-Sáez J. A. et al. (2016a) "Exploring seven hundred years of transhumance, climate dynamic, fire and human activity through a historical mountain pass in central Spain", Journal of Mountain Science 13 (2016) 1139-53.

López-Sáez J. A. et al. (2016b) "Landscape dynamics and human impact on high-mountain woodlands in the western Spanish Central System during the last three millennia", JAS: Reports 9 (2016) 203-18.

López-Sáez J. A. et al. (2014) "Vegetation history, climate and human impact in the Spanish Central System over the last 9,000 years", Quaternary International 353 (2014) 98-122.

López-Sáez J. A. et al. (2013) "Contributions to the European Pollen Database. Culazón, Cantabrian mountains (northern Spain)", Grana $5^{2}$ (2013) 316-18.

López-Sáez J. A. et al. (2010) “Late Holocene ecological history of Pinus pinaster forests in the Sierra de Gredos of central Spain", Plant Ecology 206 (2010) 195-209.

López-Sáez J. A. et al. (2009a) "Palaeoecological potential of the marine organic deposits of Posidonia oceanica: a case study in the NE Iberian Peninsula", Palaeogeography, Palaeoclimatology, Palaeoecology 271 (2009) 215-24.

López-Sáez J. A. et al. (2009b) “Contribución paleoambiental al estudio de la trashumancia en el sector abulense de la Sierra de Gredos", Hispania. Revista Española de Historia 231 (2009) 9-38.

López-Sáez J. A. et al. (2008) "Historia de la vegetación en el litoral norte de Girona entre los siglos VIII y XX d.C.: cambios climáticos y socioeconómicos desde una perspectiva paleoambiental", Arqueología y Territorio Medieval 15 (2008) 13-28.

Luterbacher J. et al. (2012) "A review of 2000 years of paleoclimatic evidence in the Mediterranean", in The Climate of the Mediterranean Region: from the Past to the Future, ed. P. Lionello (Amsterdam 2012) 87-185.

Martín-Puertas C. et al. (2011) "Geochemical processes in a Mediterranean lake: a high-resolution study of the last 4,00o years in Zoñar lake, southern Spain", Journal of Paleolimnology 46 (2011) 405-21.

Martín-Puertas C. et al. (2010) "Late Holocene climate variability in the southwestern Mediterranean region: an integrated marine and terrestrial geochemical approach", Climate of the Past 6 (2010) 807-16.

Martín-Puertas C. et al. (2008) "Arid and humid phases in southern Spain during the last 4000 years: the Zoñar lake record, Córdoba", The Holocene 18 (2008) 907-21.

Mazier F. et al. (2009) "Multidisciplinary approach to reconstructing local pastoral activities: an example from the Pyrenean Mountains (Pays Basque)", The Holocene 19 (2009) 171-88.

Mighall T. M. et al. (2006) "Proxy climate and vegetation changes during the last five millennia in NW Iberia: pollen and non-pollen palynomorph data from two ombrotrophic peat bogs in the north western Iberian Peninsula", Review of Palaeobotany and Palynology 141 (2006) 203-23.
Monna F. et al. (2004) "Environmental impact of early Basque mining and smelting recorded in a high ash minerogenic peat deposit", Science of the Total Environment 327 (2004) 197-214.

Morales-Molino C. et al. (2013) "Holocene vegetation, fire and climate interactions on the westernmost fringe of the Mediterranean basin", Quaternary Science Reviews 59 (2013) $5^{-17}$.

Morellón M. et al. (2012) "A multi-proxy perspective on millennium-long climate variability in the southern Pyrenees", Climate of the Past 8 (2012) 683-700.

Morellón M. et al. (2011) "Climate changes and human activities recorded in the sediments of lake Estanya (NE Spain) during the Medieval Warm Period and Little Ice Age", Journal of Paleolimnology 46 (2011) 423-52.

Morellón M. et al. (2009) "Lateglacial and Holocene palaeohydrology in the western Mediterranean region: the lake Estanya record (NE Spain)", Quaternary Science Reviews 28 (2009) 2582-99.

Morellón M. et al. (2008) "Holocene palaeohydrology and climate variability in northeastern Spain: the sedimentary record of lake Estanya (Pre-Pyrenean Range)", Quaternary International 181 (2008) 15-31.

Moreno A. et al. (2012) "The Medieval Climate Anomaly in the Iberian Peninsula reconstructred from marine and lake records", Quaternary Science Reviews 43 (2012) 16-32.

Muller S. D. et al. (2015) "Vegetation history of the western Rif Mountains (NW Morocco): origin, Late-Holocene dynamics and human impact", Vegetation History and Archaeobotany 24 (2015) 487-501.

Muñoz-Sobrino C. et al. (2005) "Palynological data on major Holocene climatic events in NW Iberia”, Boreas 34 (2005) 381-400.

Palet J. M. et al. (2014) "Landscape dynamics and territorial organization in the Empordà littoral plain (north-eastern Catalonia) from the Antiquity to the Medieval period: an integrated landscape analysis", in Proceedings of the 18th International Congress of Classical Archaeology: Centre and Periphery in the Ancient World, edd. J. M. Álvarez, T. Nogales and I. Rodà (Mérida 2013) 311-16.

Parra I. et al. (2005) "Análisis palinológico y radiométrico del sondeo Sobrestany. Nueve milenios de historia natural e impactos humanos sobre la vegetación del Alt Empordà", Empúries 54 (2005) 33-44.

Pèlachs A. et al. (2009) "Landscape dynamics of Abies and Fagus in the southern Pyrenees during the last 2200 years as a result of anthropogenic impacts", Review of Palaeobotany and Palynology 156 (2009) 337-49.

Pérez Díaz S. and López-Sáez J. A. (2015) "Contributions to the European Pollen Database. Fuente del Vaquero peat bog (Basque Country, Northern Iberian Peninsula, Spain)", Grana 54 (2025) 82-84.

Pérez Díaz S. and López-Sáez J. A. (2014) "Contributions to the European Pollen Database. Prados de Randulanda peat 
bog (Basque Country, Northern Iberian Peninsula, Spain)", Grana 53 (2014) 252-54.

Pérez Díaz S. and López-Sáez J. A. (2012) “Paisajes medievales: paleoambiente y antropización en Treviño en los últimos 1800 años", in Viaje a Íbita. Estudios históricos del Condado de Treviño, edd. R. González de Viñaspre and R. Garay (Treviño 2011) 377-90.

Pérez-Díaz et al. (2016a) "Seis mil años de gestión y dinámica antrópica en el entorno del Parque Natural de los Collados del Asón (Cordillera Cantábrica Oriental)", Cuaternario y Geomorfología 30 (2016) 49-74.

Pérez-Díaz et al. (2016b) "80oo years of vegetation history in the northern Iberian Peninsula inferred from the palaeoenvironmental study of the Zalama ombrotrophic bog (Basque-Cantabrian Mountains, Spain)", Boreas 45 (2016) $658-72$.

Pérez-Díaz et al. (2015) "Vegetation dynamics and human activity in the western Pyrenean region during the Holocene", Quaternary International 364 (2015) 65-77.

Pérez-Obiol R. et al. (2012) "Vegetation dynamics and anthropogenically forced changes in the Estanilles peat bog (southern Pyrenees) during the last seven millennia", Vegetation History and Archaeobotany 21 (2012) 385-96.

Pérez-Sanz A. et al. (2013) "Holocene climate variability, vegetation dynamics and fire regime in the central Pyrenees: the Basa de la Mora sequence (NE Spain)", Quaternary Science Reviews 73 (2013) 149-69.

Pérez-Sanz A. et al. (2011) "Clima y actividades humana en la dinámica de la vegetación durante los últimos 2000 años en el Pirineo central: el registro palinológico de la Basa de la Mora (Macizo de Cotiella)", Zubía. Monográfico 23 (2011) $17-38$.

Ramos-Román M. J. et al. (2016) "Centennial-scale vegetation and North Atlantic Oscillation changes during the Late Holocene in the southern Iberia", Quaternary Science Reviews 143 (2016) 84-95.

Reimer P.J. et al. (2013) "Intcal13 and marine13 radiocarbon age calibration curves 0-50,000 years cal yr BP", Radiocarbon 55 (2013) 1869-87.

Riera S. et al. (2006) "Lake responses to historical land use changes in northern Spain: the contribution of nonpollen palynomorphs in a multiproxy study", Review of Palaeobotany and Palynology 141 (2006) 127-37.

Riera S. et al. (2004) "2000-year environmental history of a karstic lake in the Mediterranean Pre-Pyrenees: the Estanya lakes (Spain)", Catena 55 (2004) 293-324.

Rius D. et al. (2012) "Holocene history of fire, vegetation and land use from the central Pyrenees (France)", Quaternary Research 77 (2012) 54-64.

Riera S. et al. (2009) "Fire frequency and landscape management in the northwestern Pyrenean piedmont, France, since the Early Neolithic (80oo cal. вP)", The Holocene 19 (2009) 847-59.
Roberts N. et al. (2012) "Paleolimnological evidence for an east-west climate see-saw in the Mediterranean since AD 9oo", Global and Planetary Change 84-85 (2012) 23-34.

Robles-López S. et al. (2017a) "The dialectic between deciduous and coniferous forests in central Iberia: a palaeoenvironmental perspective during the Late Holocene in the Gredos Range”, Quaternary International (forthcoming).

Robles-López S. et al. (2017b). "Contributions to the European Pollen Database. Labradillos mire, Gredos Range (central Spain)", Grana (forthcoming).

Ruiz Zapata M. B. et al. (2007) "Cambios en la vegetación durante el Holoceno reciente en el Valle del Lozoya (Sierra de Guadarrama, Madrid)", Revista Española de Paleontología $22(2007) 95^{-102 .}$

Rull V. and Vegas-Villarrúbia T. (2015) "Crops and weeds from the Estany de Montcortès catchement, central Pyrenees, during the last millennium: a comparison of palynological and historical records", Vegetation History and Archaeobotany 24 (2015) 699-710.

Rull V. and Vegas-Villarrúbia T. (2014) "Preliminary report on a mid-19th century Cannabis pollen peak in NE Spain: historical context and potential chronological significance", The Holocene 24 (2014) 1378-83.

Rull V. et al. (2011) "Vegetation changes in the southern Pyrenean flank during the last millennium in relation to climate and human activities: the Montcortès lacustrine record", Journal of Paleolimnology 46 (2011) 387-404.

Serrano O. et al. (2011) "The Posidonia oceanica marine sedimentary record: a Holocene archive of heavy metal pollution", Science of the Total Environment 409 (2011) 4831-40.

Silva-Sánchez N. et al. (2016) "Influence of climate change and human activities in the organic and inorganic composition of peat during the Little Ice Age (El Payo mire, Gata Range, W Spain)", The Holocene 26 (2016) 1290-1303.

Silva-Sánchez N. et al. (2014) "Linking forest cover, soil erosion and mire hydrology to Late-Holocene human activity and climate in NW Spain", The Holocene 24 (2014) 714-25.

Törnqvist T. E. et al. (1989) "Degradación antropogénica de la vegetación en el noroeste de Galicia durante los últimos 2500 años", Cuadernos de Estudios Gallegos 103 (1989) 175-98.

Valero-Garcés B. L. et al. (2006) "Human impact since medieval times and recent ecological restoration in a Mediterranean lake: the Laguna Zoñar, southern Spain", Journal of Paleolimnology 35 (2006) 441-65.

Van der Knaap W. O. and van Leeuwen J. F. N. (1995) “Holocene vegetation and degradation as responses to climatic change and human activity in the Serra da Estrela, Portugal", Review of Palaeobotany and Palynology 89 (1995) 153-211.

Vannière B. et al. (2001) "Feu et pratiques agro-pastorales dans les Pyrénées Orientales: le cas de la montagne d'Enveitg (Cerdagne, Pyrénées-Orientales, France)", Sud-Ouest Européen 11 (2001) 29-42. 